Canadian Science Publishing

Canadian Journal of Earth Sciences Revue canadienne des sciences de la Terre

\title{
Geology of the orogenic Cheminis gold deposit along the Larder Lake-Cadillac deformation zone, Ontario
}

\begin{tabular}{|r|l|}
\hline Journal: & Canadian Journal of Earth Sciences \\
\hline Manuscript ID & cjes-2015-0067.R1 \\
\hline Manuscript Type: & Article \\
\hline Date Submitted by the Author: & 21 -Sep-2015 \\
\hline Complete List of Authors: & $\begin{array}{l}\text { Lafrance, Bruno; Laurentian University, Department of Earth Sciences, } \\
\text { Mineral Exploration Research Centre }\end{array}$ \\
\hline Keyword: & $\begin{array}{l}\text { Larder Lake - Cadillac deformation zone, Cheminis mine, orogenic gold } \\
\text { deposit, Kerr Addison mine, Archean Abitibi Subprovince }\end{array}$ \\
\hline \multicolumn{2}{|l}{} \\
\hline
\end{tabular}

SCHOLARONE ${ }^{\text {IM }}$

Manuscripts 
Geology of the orogenic Cheminis gold deposit along the Larder Lake-Cadillac deformation zone, Ontario

Bruno Lafrance

Mineral Exploration Research Centre, Department of Earth Sciences, Goodman School of Mines, Laurentian University, Ramsey Lake Road, Sudbury, ON, Canada P3E 2C6 Tel: (705)675-1151 extension 2264,Email: blafrance@laurentian.ca 


\begin{abstract}
The Larder Lake - Cadillac deformation zone (LLCDZ) is one of two major, auriferous, deformation zones in the southern Abitibi subprovince of the Archean Superior Province. It hosts the Cheminis and the giant Kerr Addison - Chesterville deposits within a strongly deformed band of Fe-rich tholeiitic basalt and komatiite of the Larder Lake Group (ca. 2705 Ma). The latter is bounded on both sides by younger, less deformed, Timiskaming turbidites (2674 Ma - $2670 \mathrm{Ma}$ ). The earliest deformation features are $\mathrm{F}_{1}$ folds affecting the Timiskaming rocks, which formed either during $\mathrm{D}_{1}$ extensional faulting or during early $\mathrm{D}_{2}$ north-south shortening related to the opening and closure, respectively, of the Timiskaming basin. Continued shortening during $\mathrm{D}_{2}$ imbricated the older volcanic rocks and turbidites and produced regional $\mathrm{F}_{2}$ folds with an axial planar $\mathrm{S}_{2}$ cleavage. $\mathrm{D}_{2}$ deformation was partitioned into the weaker band of volcanic rocks, producing the strong $\mathrm{S}_{2}$ foliation, $\mathrm{L}_{2}$ stretching lineation, and south-side-up shear sense indicators, which characterize the LLCDZ.
\end{abstract}

Gold is present in quartz-carbonate veins in deformed fuchsitic komatiites (carbonate ore) and turbiditic sandstone (sandstone-hosted ore), and in association with disseminated pyrite in altered Fe-rich tholeiitic basalts (flow ore). All host rocks underwent strong mass gains in $\mathrm{CO}_{2}$, $\mathrm{S}, \mathrm{K}_{2} \mathrm{O}, \mathrm{Ba}$, As, and $\mathrm{W}$, during sericitization, carbonatization, and sulphidation of the host rocks, suggesting that they interacted with the same hydrothermal fluids. Textural relationships between alteration minerals and $\mathrm{S}_{2}$ cleavage indicate that mineralization is syn-cleavage. Thus, gold was deposited as hydrothermal fluids migrated upward along the LLCDZ during contractional, $\mathrm{D}_{2}$ south-side-up shearing. The gold zones were subsequently modified during $\mathrm{D}_{3}$ reactivation of the LLCDZ as a dextral transcurrent fault zone.

Keywords: Orogenic gold deposit, Larder Lake - Cadillac deformation zone, Abitibi, flow ore, Cheminis mine, Kerr Addison mine, structural controls on gold, Superior Province 


\section{Introduction}

Two major breaks or deformation zones are associated with gold deposits in the southern Abitibi subprovince: the Porcupine-Destor deformation zone to the north, which extends from Timmins in Ontario to Destor in Quebec, and the Larder Lake-Cadillac deformation zone (LLCDZ) to the south, which can be traced from Matachewan in Ontario to Val D'Or in Quebec (Fig. 1). The two breaks are further characterized by their spatial association with fluvial conglomerate and sandstone of the Timiskaming Group, intense carbonate alteration, and strongly foliated and lineated ultramafic rocks and Fe-rich tholeiitic basalts (Thompson 1941; Cameron 1993; Smith et al. 1993; Poulsen et al. 2000; Ispolatov et al. 2005, 2008; Dubé and Gosselin 2007). These features all played important roles in the formation of gold deposits along the breaks and their significance will be further explored here for the Cheminis and other deposits located along the LLCDZ in Ontario.

The LLCDZ is a $250 \mathrm{~km}$ long, curviplanar structure with an overall east-west trend. It consists of east-trending segments separated by shorter northwest- and northeast-trending segments. It is generally south-dipping west of the Cheminis mine (Fig. 1) and north-dipping from the Cheminis mine eastward to Val d'Or. From Kirkland Lake to Larder Lake (Fig. 2), it generally follows the contact between Timiskaming conglomerates and alkaline volcanic rocks (ca. $2680 \mathrm{Ma}$ - ca. $2670 \mathrm{Ma}$; Ayer et al. 2005), and older volcanic rocks of the Larder Lake Group (ca. 2705 Ma; Corfu et al. 1989). East of Larder Lake, it leaves this contact to follow a narrow, $100 \mathrm{~m}-350 \mathrm{~m}$ wide, band of ultramafic rocks and Fe-rich tholeiitic basalts of the Larder Lake Group, which is surrounded on both sides by deeper marine turbiditic sandstones of the Hearst assemblage (Hyde 1980). The LLCDZ can be traced up to $2.8 \mathrm{~km}$ west of the OntarioQuebec provincial border before it disappears under cover rocks of the Paleoproterozoic 
Huronian Supergroup only to reappear $33 \mathrm{~km}$ farther to the east, south of Rouyn-Noranda in Quebec.

In contrast to the Quebec segment of the LLCDZ, where deposits occur along both the main structure and higher order structures (Robert 1989), almost all deposits in Ontario occur along the main structure (Ispolatov et al. 2005, 2008). From Larder Lake to the Ontario-Quebec border, these include the giant Kerr Addison - Chesterville deposit and the smaller satellite Armistice, Barber Lake, Cheminis, Fernland and Omega deposits (Fig. 2). Excellent new exposures of the ore zones at the Cheminis mine, and a recent shallow drill program across the zones, provided excellent new sections that were used to characterize the structural controls on mineralization and the styles of alteration and mineralization along this prolific segment of the LLCDZ. Interpretation of this new data addresses several key questions on the structural evolution and timing of gold mineralization along the LLCDZ. Is the LLCDZ a transcurrent tranpression zone (Wilkinson et al. 1999), a reactivated syn-depositional extensional fault (Dimroth et al. 1982; Cameron 1993; Bleeker 2012), or a reverse, south- or north-side-up shear zone (Hodgson and Hamilton 1989; Hodgson et al. 1991; Smith et al. 1993; Ispolatov et al. 2008; Bleeker 2012; Zhang et al. 2014)? Was gold emplaced during early extension and formation of the Timiskaming basin (Cameron 1993; Bleeker 2012), during closure and shortening of the basin (Hodgson and Hamilton 1989; Cameron 1993; Ispolatov et al. 2008; Bleeker 2012), or during later dextral transcurrent movement (Neumayr et al. 2000, 2007; Bedeaux et al. 2014)? Was deep-seated alkaline magmatism the source of the gold-bearing hydrothermal fluids (Cameron 1993; Smith et al. 1993; Bleeker 2012)? These key questions on the formation of gold deposits in the southern Abitibi subprovince are discussed in the paper following a description of the host rocks, structures and ore zones at the Cheminis mine. 


\section{Analytical techniques}

\section{Geochemistry}

Thirty-two samples of Fe-rich tholeiitic basalt (19), komatiite (7), syenite (3), and sandstone (3) were collected from drill core and outcrop on the Cheminis mine site. Representative analyses are listed in Table 1. All analyses were done at Activation Laboratories in Ancaster, Ontario, Canada. Lithium metaborate and tetraborate fused samples were analysed for major elements and trace elements $(\mathrm{V}, \mathrm{Sr}, \mathrm{Ba})$ using the inductively coupled plasma emission spectrometry (ICP) technique, and for trace elements (Co, Ga, Ge, Rb, Y, Zr, Nb, Sb, Sb, Cs, Bi, Rare Earth Elements (REE), Hf, Ta, W, Tl, Th, U) using the inductively coupled plasma emission mass spectrometry (ICP-MS) technique. Precision is typically better than $5 \%$ for major elements (except $\mathrm{K}_{2} \mathrm{O}$ ) and REE and 10\% for other trace elements. Base metals (Cd, Ni, Cu, Zn), $\mathrm{Ag}$, and $\mathrm{S}$ concentrations were measured using a four acid digestion ICP technique with precision and accuracy better than $10 \%$ except for values close to detection limits. Au and trace elements (As, $\mathrm{Cr}, \mathrm{Sc}, \mathrm{Sb}$ ) concentrations were determined by instrumental neutron activation analysis (INAA) with precision and accuracy better than $6 \% . \mathrm{CO}_{2}$ concentrations were measured by coulometry using the absorption of infrared energy. Their precision and accuracy are better than $2 \%$. A subset of fourteen mineralized samples was prepared as aqua regia digestions and analyzed for $\mathrm{Au}, \mathrm{Ag}, \mathrm{As}, \mathrm{W}, \mathrm{Zn}, \mathrm{Cu}, \mathrm{Pb}, \mathrm{Bi}, \mathrm{Te}, \mathrm{Mo}, \mathrm{Sb}$, Sn, Se using the ICP-MS technique.

\section{Mineral chemistry}

Mineral chemistries were determined using an Oxford Sight energy dispersive detector mounted on a JEOL 6400 scanning electron microscope at the Central Analytical Facility of Laurentian University. Data acquisition was done at an accelerating voltage of $15 \mathrm{kV}, 1.005 \mathrm{nA}$ beam 
current, acquisition count times of $60 \mathrm{~s}$, and a working distance of $15 \mathrm{~mm}$. Well characterized jadeite, diopside, orthoclase, corundum, quartz, and pyrophanite were used as standards.

\section{Rock description}

\section{Field and petrographic description}

In the Cheminis area, the mafic and ultramafic rocks of the Larder Lake Group occur along the LLCDZ. They are all weakly to strongly hydrothermally altered. Least-altered mafic volcanic rocks are generally fine-grained and dark green to dark grey on outcrop surfaces. They consist of chlorite, albite, ankerite, and quartz \pm rutile and pyrite. They occur as massive flows or intrusions, variolitic pillowed flows, and volcaniclastic rocks. The massive flows or intrusions are typically strongly lineated and weakly foliated. The variolitic pillowed flows consist of aphyric pillows that are strongly flattened parallel to foliation. The variolites occur along pillow margins as lighter grey to green, ellipsoidal lumps that are also flattened parallel to foliation. The volcaniclastic rocks comprise aphyric mafic clasts that are up to $9 \mathrm{~cm}$ in size. They are found south of the LLCDZ, where they are strongly lineated but only weakly foliated.

The ultramafic rocks invariably underwent strong hydrothermal alteration. Three types are present: black talc-chlorite, grey chlorite-carbonate, and green fuchsite-carbonate ultramafic rocks. The latter two are massive to strongly foliated with dark rusty brown, pitted, outcrop surfaces dissected by multiple cooling cracks. Chlorite-carbonate ultramafic rocks are grey to light yellow or pale brown on fresh surfaces. They consist of chlorite, albite, ferroan dolomite, magnesite, and quartz. Fuchsite-carbonate ultramafic rocks are apple green on fresh surfaces, and they have similar mineralogies as the chlorite-carbonate ultramafic rocks, except for the presence of fuchsite instead of chlorite \pm apatite. Talc-chlorite ultramafic rocks are strongly foliated and 
black on fresh and outcrop surfaces. They are composed of talc, chlorite, albite, ferroan dolomite, quartz and rutile. They are friable and recessive due to weathering, and are only exposed along trenches.

Timiskaming sedimentary rocks are represented by conglomerate and sandstone. The conglomerate comprises clasts of red and black chert, quartz vein, mafic volcanic rocks, reddish feldspar-phyric syenite, hornblende-phyric granitoid, and mudstone. The clasts are surrounded by a chloritic, green, sandy matrix. Conglomeratic beds are interlayered with massive sandstone beds. Turbidite sandstone of the Hearst assemblage consists of interlayered mudstone and well graded, locally trough cross-bedded, sandstone. It is locally interbedded with $10-20 \mathrm{~cm}$ thick, horizons of iron formation, consisting of black, laminated, magnetite-bearing layers and red jasper layers.

Timiskaming igneous rocks include trachyte flows, trachytic volcaniclastic rocks, and syenite dikes. In the Cheminis area, only the latter is present along the LLCDZ and is described herein. Syenite dikes are light grey on fresh surfaces and pinkish grey on outcrop surfaces. They are aphyric to plagioclase-phyric with a very-fine-grained to aphanitic matrix. Although the dikes occur along the LLCDZ, they are unfoliated to weakly foliated in contrast to their surrounding, more strongly foliated, mafic and ultramafic host rocks.

\section{Geochemistry}

The composition of all rock types is represented on the cation classification diagram of Jensen and Pyke (1982). The mafic rocks and ultramafic rocks plot in distinct fields (Fig. 3a). All ultramafic rocks plot in the komatiite and komatiitic basalt fields, whereas the mafic volcanic rocks plot almost entirely within the high-Fe tholeiitic basalt field. Timiskaming syenite dike 
and turbiditic sandstone cluster together within the calc-alkaline basalt and andesite fields. A $\mathrm{TiO}_{2}$ versus $\mathrm{Zr}$ binary diagram further illustrates the differences in their compositions (Fig. 3b). With one exception, ultramafic rocks have low $\mathrm{TiO}_{2}$ (average of 0.40 weight $\%$ ) and $\mathrm{Zr}$ (average of $22 \mathrm{ppm})$ concentrations. The mafic volcanic rocks have higher $\mathrm{TiO}_{2}(0.8-2.2$ weight $\%)$ and $\mathrm{Zr}(66-211 \mathrm{ppm})$ concentrations. The syenite dikes have low $\mathrm{TiO}_{2}(0.5-0.8$ weight \%) and high $\operatorname{Zr}(150-190 \mathrm{ppm})$ concentrations. The turbiditic sandstones contain $0.7-1.0$ weight \% $\mathrm{TiO}_{2}$ and $90-140 \mathrm{ppm} \mathrm{Zr}$. They are intermediate in composition between the syenite dikes and the mafic and ultramafic rocks.

The trace element composition of the syenite dikes and turbiditic sandstones are further investigated on a rare-earth element (REE) diagram normalized to chondrite (Fig. 4a) and on an extended trace element diagram normalized to primitive mantle (Fig. 4b). On the REE diagram, syenite and turbiditic sandstone are both strongly enriched in light REE with $(\mathrm{La} / \mathrm{Yb})_{\mathrm{N}}=9-20$ and 5-6, respectively. Their total light REE concentrations range from 20 - 200 times chondrite in syenite, and from 20 - 70 times chondrite in turbiditic sandstone. On the extended trace element diagram, syenite shows strong negative $\mathrm{Nb}, \mathrm{Ta}, \mathrm{P}, \mathrm{Ti}, \mathrm{Sc}$ anomalies, and turbiditic sandstone has the same but slightly less pronounced anomalies.

\section{Structural Geology}

The earliest deformation features in the Cheminis mine area are post-Timiskaming, mapscale, isoclinal, $F_{1}$ folds. The folds are located immediately east of a syenite stock in the western part of the map area (Fig. 5). These folds, which lack an axial plane cleavage, are defined by reversals in younging direction in turbiditic sandstone and conglomerate. They are overprinted by map-scale, $\mathrm{F}_{2}$ folds with a strong axial planar $\mathrm{S}_{2}$ cleavage, which is expressed as a sericitic 
and chloritic slaty cleavage in mudstone and as a disjunctive cleavage defined by opaque minerals in sandstone. $\mathrm{S}_{2}$ cleavage strikes east to east-northeast and dips steeply $\left(75^{\circ}-85^{\circ}\right)$ to the south or north (Fig. 5). $\mathrm{F}_{2}$ fold axes and $\mathrm{S}_{2}$-bedding intersection lineations plunge $55^{\circ}$ to $75^{\circ}$ to the east or west (Fig. 5). Within $200 \mathrm{~m}$ of the LLCDZ, the folds are replaced by a southyounging, homoclinal panel of turbiditic sandstone with $\mathrm{S}_{2}$ oriented consistently anticlockwise to bedding. North of the LLCDZ, beds remain south-younging but $\mathrm{S}_{2}$ is oriented clockwise to bedding and therefore has an opposite angular relationship to bedding to that described in the homoclinal panel immediately south of the LLCDZ.

The LLCDZ is characterized by a strong $\mathrm{S}_{2}$ cleavage and a down-dip, steeply-plunging $\left(70^{\circ}-80^{\circ}\right), \mathrm{L}_{2}$ lineation. Strain and alteration are heterogeneously distributed within the deformation zone. In weakly altered mafic volcanic rocks, $\mathrm{S}_{2}$ is a wriggly disjunctive cleavage defined by opaque minerals and chlorite. Within more altered rocks, $\mathrm{S}_{2}$ is defined by sericite and chlorite, by carbonate-rich microlithons with elongate carbonate grains, and by pyrite cubes with strain shadows infilled with carbonate, quartz, and sericite. In altered and foliated ultramafic rocks, $\mathrm{S}_{2}$ is defined by fuchsite, talc, sericite, and chlorite, alternating with microlithons of crenulated talc and/or elongate carbonate grains. In strongly deformed conglomerate and mafic volcaniclastic rocks, $\mathrm{S}_{2}$ is further defined by the flattening of the clasts. $\mathrm{L}_{2}$ is usually expressed as a mineral lineation defined by alternating dark streaks of chlorite, fuchsite, and sericite and lighter streaks of carbonate. In weakly foliated to massive ultramafic rocks, $\mathrm{L}_{2}$ is further expressed by stretched pseudo fragments bounded by deformed polygonal cooling joints or cracks.

Few $\mathrm{D}_{2}$ shear sense indicators are present along the LLCDZ. All are observed on surfaces perpendicular to foliation and parallel to lineation and suggest south-side-up movement 
up the plunge of the lineation $\left(\mathrm{L}_{2}\right)$. Shear sense indicators include shear bands, quartz fibers in asymmetrical strain shadows around pebbles in sheared conglomerate, oblique $\mathrm{S}$-fabrics in $\mathrm{S}_{2}$ parallel chlorite bands (Fig. 6a), and S-shape fabrics defined by elongate recrystallized quartz grains in sheared quartz veins (Fig. 6b).

$\mathrm{S}_{2}$ is overprinted by $\mathrm{F}_{3}$ folds with an axial planar $\mathrm{S}_{3}$ cleavage. The folds have $\mathrm{Z}$-shaped asymmetry and plunge $30^{\circ}-60^{\circ}$ to the east-northeast and west-southwest (Fig. 5). $\mathrm{S}_{3}$ strikes $040^{\circ}$ $-080^{\circ}$, dips steeply $\left(70^{\circ}-90^{\circ}\right)$ to the south or north (Fig. 5), and is typically oriented anticlockwise to bedding and $\mathrm{S}_{2}$. It is expressed as a chloritic and sericitic slaty cleavage in mudstone, as a disjunctive cleavage in interlayered sandstone, and as a crenulation cleavage overprinting $\mathrm{S}_{2}$ in strongly foliated ultramafic rocks along the LLCDZ. Late dextral shear bands, which overprint $\mathrm{S}_{2}$ along the LLCDZ, likely formed during the same deformation event as $\mathrm{F}_{3}$ and $\mathrm{S}_{3}$.

\section{Mineralization}

In 1937 and 1938, Consolidated Mining and Smelting Company of Canada discovered the Cheminis deposit through diamond drilling (Thomson 1941). A shaft was sunk late in 1938 and mining was completed to the 525-foot level (Thomson 1941). The mine closed in 1940, reopened in 1947, and closed again after deepening the shaft to 1,085 feet and developing the 1035-foot mine level. From 1991 - 1996, the mine was briefly in operation and produced 17,530 ounces of gold from 179,013 tons of ore. In 2004 - 2006, extensive drilling programs were completed, including $2541 \mathrm{~m}$ from 35 shallow drill holes. The samples described herein come from these drill holes. 
Ore zones occur along the LLCDZ where they are spatially associated with a south panel of ultramafic rocks with slivers of Fe-rich tholeiitic basalt, and a north panel of ultramafic rocks (Fig. 7). The two panels are separated by strongly lineated but otherwise texturally massive Ferich tholeiitic basalt and are bounded to the south and north by turbiditic sandstone (Fig. 7). The south panel hosts the A, B, and C flow ore zones (Figs. 7, 8). The latter are within slivers of Ferich tholeiitic basalt surrounded by green fuchsite-carbonate ultramafic rock, in turn flanked by an inner shell of grey chlorite-carbonate ultramafic rock and an outer shell of black talc-chlorite ultramafic rock (Fig. 7). Immediately south of the panel, minor mineralized zones, the South and North Sediment gold zones, are hosted by turbiditic sandstone along and within $20 \mathrm{~m}$ of their contact with the ultramafic rocks, respectively. The two zones, which lack surface expression, are shown on mine level plans (Fig. 8). The north panel hosts the No. 1 and No. 2 North Carbonate gold zones, which also lack surface expression and are shown in Figure 8.

\section{Flow ore}

The A and C flow ore zones are exposed at surface as 5-8 m thick, $\mathrm{S}_{2}$-parallel, slivers, which can be traced along strike for $75 \mathrm{~m}$ and $40 \mathrm{~m}$, respectively. The zones are moderately to strongly $\mathrm{S}_{2}$ foliated and $\mathrm{L}_{2}$ lineated. $\mathrm{S}_{2}$ is defined by sericite foliation planes interleaved with ankerite microdomains, and by Fe-Ti oxide and non-reflective opaque material along disjunctive foliation planes. The ore zones typically contain up to $15 \%$ pyrite surrounded by a fine-grained, dark to light grey, matrix. Few quartz-carbonate veins cut across $\mathrm{S}_{2}$.

Unmineralized and mineralized high-Fe tholeiitic basalts have similar mineralogy. Mineralized high-Fe tholeiitic basalt consists of ankerite, sericite, chlorite, albite, pyrite, quartz, Fe-Ti oxide and rutile. Mineralized basalt has undergone more extensive ankerite alteration (up 
to $65 \%$ of the rock) than the unmineralized high-Fe tholeiitic basalt ("least-altered precursor"), and sericite has largely replaced chlorite, which is a major fabric-forming mineral in the leastaltered precursor. Ankerite, sericite and chlorite differ in their mineral chemistry and are more Mg-rich (higher Mg numbers) in mineralized basalt relative to their least-altered precursor (Table 2). Following Grant (1986), gains and losses in major oxides and trace elements during mineralization are represented on a $\%$ mass change histogram that compares the composition of the mineralized basalt to that of its least-altered precursor (Fig. 9). Mineralized basalt underwent strong mass gains in $\mathrm{K}_{2} \mathrm{O}, \mathrm{Rb}, \mathrm{Ba}, \mathrm{CaO}, \mathrm{MgO}, \mathrm{CO}_{2}, \mathrm{~S}$, As, and significant losses in $\mathrm{SiO}_{2}$ and $\mathrm{Na}_{2} \mathrm{O}$ (Fig. 9a). Binary molar diagrams of $\mathrm{CaO} / \mathrm{Al}_{2} \mathrm{O}_{3}, \mathrm{MgO} / \mathrm{Al}_{2} \mathrm{O}_{3}, \mathrm{CO}_{2} / \mathrm{Al}_{2} \mathrm{O}_{3}$ versus $\mathrm{K}_{2} \mathrm{O} / \mathrm{Al}_{2} \mathrm{O}_{3}$ show strong positive correlations between $\mathrm{K}_{2} \mathrm{O}, \mathrm{MgO}, \mathrm{CaO}$, and $\mathrm{CO}_{2}$ (Fig. 10). This reflects the strong ankerite and sericite alteration of the host rock and the increase in $\mathrm{Mg \#} \mathrm{of}$ ankerite, chlorite, and sericite in the mineralized basalt relative to the unmineralized basalt.

Pyrite is the dominant sulphide mineral in the ore zones. It occurs as small grains $(<1$ $\mathrm{mm}$ in size) localized along $\mathrm{S}_{2}$ and as large, euhedral, pyrite cubes (up to $5 \mathrm{~mm}$ in size) that truncate $S_{2}$ (Fig. 11a) and are surrounded by $S_{2}$. Sericite and ankerite occur in strain shadows around pyrite cubes (Fig. 11b) and as inclusions in pyrite (Fig. 11c). The two textural types of pyrite lack Ni and Co but contain similar As concentrations (up to 0.43 atomic \%) in both core and rim. Chalcopyrite, arsenopyrite and sphalerite are present as inclusions in pyrite and as disseminations in the matrix of the rock.

Gold is associated with both types of pyrite. Gold grains with Au/Ag ratios of 5 to 12 occur as inclusions in pyrite (Fig. 11d) and along pyrite grain boundaries (Fig. 11e). A later generation of gold grains with lower $\mathrm{Au} / \mathrm{Ag}$ ratio of 4 to 5 occur with covellite in late fractures cutting across pyrite grains (Fig. 11f). 


\section{Ultramafic-hosted mineralization}

Sulphide minerals constitute less than $2-3 \%$ of the ultramafic rocks. In addition to pyrite, barite and other sulphide minerals, such as cobaltite, chalcopyrite, siegenite, gersdorffite, ullmannite and millerite, occur as disseminated grains in the matrix of the rock. The green fuchsite-carbonate ultramafic rock typically contains more sulphide minerals than the talcchlorite and chlorite-carbonate ultramafic rocks. This is manifested by strong mass gains in $\mathrm{S}$ and metals (As, W, Sb), as well as $\mathrm{K}_{2} \mathrm{O}, \mathrm{Na}_{2} \mathrm{O}$ and $\mathrm{Ba}$, in the fuchsite-carbonate ultramafic rock relative to that of the other two types of ultramafic rocks (Fig. 9b).

In contrast to the flow ore, multiple vein sets are present in the ultramafic rocks. The earliest vein set consists of grey quartz-carbonate veins that are strongly folded, boudinaged and transposed parallel to $S_{2}$. The veins are a few cms to less than $1 \mathrm{~cm}$ thick and they commonly have fuchsitic selvedges. They are zoned with blocky carbonate grains along the vein walls and anhedral quartz grains in the center of the veins. Drill core intervals with an abundance of those veins are typically enriched in gold. A second vein set consists of breccia veins with strongly carbonatized fragments of the host ultramafic rocks. One of these veins is $1 \mathrm{~m}$ thick and is exposed over $5 \mathrm{~m}$ along strike of $\mathrm{S}_{2}$ in the southern ultramafic panel. A down-dip lineation is present along the vein wall and an oblique shape fabric, visible optically only, is defined by recrystallized, elongate, small quartz grains, suggesting reverse, south-side-up movement parallel to the vein wall. A third vein set consists of shallowly-dipping, fibrous to massive, quartzcarbonate veins cutting across $S_{2}$. The veins are folded by Z-shaped $F_{3}$ folds suggesting that they were emplaced after $D_{2}$ but before $D_{3}$. A swarm of those veins cut across a syenite dike hosted 
by ultramafic rocks, east of the A zone. The dike strikes parallel to $S_{2}$ and is weakly foliated parallel to $\mathrm{S}_{2}$. It is one of only three syenite dikes found in the Cheminis mine area.

\section{Sandstone-hosted mineralization}

Sandstone-hosted mineralization consists of fibrous quartz-carbonate veins surrounded by an alteration haloe of ankerite, sericite, arsenopyrite and pyrite. The host least-altered sandstone consists of fine-grained chlorite, biotite, sericite, carbonate, quartz, albite and rutile. Alteration haloes surrounding the veins are marked by increases in ankerite abundance, the disappearance of chlorite, the coarsening of sericite, and the addition of up to $5 \%$ arsenopyrite and pyrite. Arsenopyrite is the most abundant sulphide mineral followed by pyrite and then disseminated chalcopyrite, tetrahedrite and gersdorffite. Chalcopyrite occupies fractures in arsenopyrite and is also present as small irregular grains along arsenopyrite grain boundaries. The mineralogical changes from unmineralized to mineralized sandstones correlate with variable mass gains in $\mathrm{CaO}$ and $\mathrm{CO}_{2}$, and strong mass gains in $\mathrm{S}, \mathrm{As}, \mathrm{W}$, and $\mathrm{Sb}$ (Fig. 9c). Only one gold grain was found. It has a gold to silver ratio of 5, and it fills intersecting fractures or cleavage planes within arsenopyrite.

\section{Interpretation and Discussion}

Observations and data presented in this study provide new insights on the origin of the turbiditic sandstone, the structural evolution of the LLCDZ, and the formation of gold deposits along the LLCDZ, as discussed below. 


\section{Origin of turbiditic sandstone}

From Larder Lake to Virginiatown, the LLCDZ occurs along a band of mafic and ultramafic volcanic rocks, which is bounded to the north and south by turbiditic sandstone. The origin of the turbiditic sandstone is controversial (Ayer et al. 2005). Hyde (1980) interpreted these rocks as resedimented submarine fan turbidites equivalent in age to the Timiskaming fluvial conglomerate and sandstone. Alternatively, Jensen and Langford (1985), Corfu et al. (1991), and Mueller et al. (1994) suggested that the turbidite sandstones represent an older sedimentary sequence similar to the Porcupine assemblage in the Timmins area, where it is unconformably overlain by the Timiskaming Group.

The whole rock geochemistry of the turbiditic sandstone reflects the origin of the rock. On a $\mathrm{TiO}_{2}$ versus $\mathrm{Zr}$ binary diagram, turbiditic sandstone is intermediate in composition to the syenite and the mafic and ultramafic volcanic rocks. It shows similar but weaker light REE enrichment, and the same but less pronounced negative anomalies in $\mathrm{Nb}, \mathrm{Ta}, \mathrm{P}, \mathrm{Ti}, \mathrm{Sc}$, as those of the syenite dike. This suggests that the turbiditic sandstone is derived from the erosion of Timiskaming alkaline rocks and older mafic and ultramafic volcanic rocks similar to the Larder Lake Group. This interpretation is consistent with the detrital zircon age of these rocks. Samples of turbiditic sandstone, which were collected south of Highway \#66 near the main entrance of the Cheminis mine (detailed outcrop map in Fig. 4 of Wilkinson et al. 1999) yielded Timiskaming ages of $2674 \pm 3.7 \mathrm{Ma}$ and $2684.9 \pm 1.9 \mathrm{Ma}$ (Ayer et al. 2002). Thus, as argued by Ayer et al. (2005), the turbiditic sandstone represents a deeper marine facies of the Timiskaming assemblage as initially proposed by Hyde (1980) rather than an older Porcupine-like sedimentary succession as later suggested by Jensen and Langford (1985), Corfu et al. (1991), and Mueller et al. (1994). 


\section{Structural evolution of the $L L C D Z$}

The LLCDZ formed as deformation during the $\mathrm{D}_{2}$ event became localized along the contact between the Timiskaming assemblage and the Larder Lake Group, west of Larder Lake, and along the band of Larder Lake volcanic rocks, east of Larder Lake. During the $\mathrm{D}_{2}$ deformation, the Timiskaming rocks and Larder Lake volcanic rocks were tilted, imbricated, and overprinted by $\mathrm{F}_{2}$ folds and axial planar, regional, $\mathrm{S}_{2}$ cleavage. With continued shortening during $\mathrm{D}_{2}$, the simple shear component of the deformation was partitioned within the Larder Lake volcanic rocks and along their contact with the Timiskaming rocks, resulting in the formation of the pronounced $\mathrm{S}_{2}$ cleavage and steeply-plunging $\mathrm{L}_{2}$ lineation that characterize the LLCDZ. The $\mathrm{D}_{2}$ deformation is constrained in age between $2672 \pm 2 \mathrm{Ma}$, the U-Pb zircon crystallization age of the syenitic Murdoch Creek pluton, and $2665 \pm 4 \mathrm{Ma}$, the U-Pb age of syn-S $\mathrm{S}_{3}$ titanite (Wilkinson et al. 1999).

In the Cheminis mine area, the LLCDZ and Larder Lake volcanic rocks are bounded on both sides by Timiskaming turbiditic sandstone with the same south-younging direction but opposite $\mathrm{S}_{2}$-bedding angular relationships. This geometry can be explained by fault repetition of the south-younging limb of a doubly-plunging $F_{2}$ fold. $F_{2}$ folds plunge both to the east and west (Fig. 5), therefore it is plausible that a regional $F_{2}$ fold, now dismembered by faults, had a doubly-plunging fold axis. The reversal in the plunge of the fold could have been caused either by overprinting of the fold by a younger fold generation, or by rotation of its fold axis during stretching parallel to the steeply-plunging $\mathrm{L}_{2}$ lineation. In either case, its axial planar $\mathrm{S}_{2}$ cleavage would have changed in relative angular orientation from anticlockwise, to parallel, to clockwise to bedding along the same fold limb. If the south-younging limb of the fold were then to be 
repeated by limb- or bedding-parallel faults, then the relative orientation of $\mathrm{S}_{2}$ to bedding would change across the LLCDZ without reversal in the younging direction, as observed in the Cheminis mine area. This would further explain the imbrication of the Timiskaming turbiditic sandstone and Larder Lake volcanic rocks, prior to the partitioning of the deformation along the band of Larder Lake volcanic rocks. The early map-scale $F_{1}$ folds in the western part of the study area (Fig. 5) could be coeval with the imbrication of the turbiditic sandstone and volcanic rocks (Pilote et al. 2014), or they may have formed during an older $\mathrm{D}_{1}$ deformation event associated with extensional faulting during formation of the Timiskaming basin (Bleeker 2012).

The shallowly-dipping, non-auriferous, quartz-carbonate veins, which overprint $\mathrm{S}_{2}$, mark a hiatus between the $\mathrm{D}_{2}$ and $\mathrm{D}_{3}$ deformations. The veins are typically straight and undeformed except where folded by $\mathrm{Z}$-shaped $\mathrm{F}_{3}$ folds. Thus, they were emplaced after the $\mathrm{D} 2$ deformation and before the late $\mathrm{D}_{3}$ dextral transcurrent reactivation of the LLCDZ.

Wilkinson et al. (1999) proposed a different structural interpretation for the LLCDZ. They interpreted the bends or changes in trend along the LLCDZ as early features predating the $\mathrm{D}_{2}$ deformation. Thus, they suggested that north-south shortening during $\mathrm{D}_{2}$ caused sinistral transpression along NE-trending segments, dextral transpression along SE-trending segments, and only contraction (or compression) along E-trending segments. The slip directions along the NE- and SE-trending segments were interpreted to be sub-horizontal and therefore oblique to the stretching lineation as modelled and observed in triclinic transpression zones with a dominant transcurrent component (Sanderson and Marchini 1984; Robin and Cruden 1993; Lin et al. 1998). However, along all segments of the LLCDZ from the Young-Davidson mine in Matachewan (Zhang et al. 2014), to Kirkland Lake (Thompson et al. 1950), to the McBean mine in Dobie (Ispolatov et al. 2005), the Cheminis mine in Larder Lake (this study), and the Kerr- 
Addison mine in Virginiatown (Smith et al. 1993), the slip direction is south-side-up parallel to the stretching lineation. It is not oblique or perpendicular to the stretching lineation, as observed in triclinic transpression zones or transcurrent transpression zones, respectively (Robin and Cruden 1993; Lin et al. 1998). Furthermore, the attitude of the $S_{2}$ cleavage mimics the changes in orientation of the LLCDZ. E-trending segments are neither offset along the sinistral NE-trending segments nor are they offset along the dextral SE-trending segments. This suggests that the bends along the LLCDZ do not represent early pre-D2 feature as proposed by Wilkinson et al. (1999). They are late features that either formed during $F_{3}$ folding or during north-trending open folding, as suggested by Ispolatov et al. $(2005,2008)$ for the Dobie area, west of Larder Lake. The LLCDZ has a more pronounced $\mathrm{S}_{2}$ cleavage and $\mathrm{L}_{2}$ stretching lineation than the turbiditic sandstones surrounding it, suggesting that it underwent shortening and extension perpendicular and parallel to its boundaries, respectively. Thus, the LLCDZ is transpressional, but it is not a transcurrent transpression zone or triclinic transpression zone with a dominant transcurrent character as proposed by Wilkinson et al. (1999). Rather, it formed as a reverse, south-side-up, shear zone, which underwent shear during shortening perpendicular to its boundaries and stretching parallel to the slip direction.

\section{Gold deposits along the LLCDZ}

The three styles of gold mineralization at the Cheminis mine reflect the composition of the host rocks. Mineral chemistries differ amongst host rocks, but strongly altered rocks have the same simple mineralogy regardless of their initial composition. All consists of white mica (sericite or fuchsite), carbonate (ankerite or ferroan dolomite), chlorite, quartz, and albite (Table 2), suggesting high hydrothermal fluid to rock ratios (Kishida and Kerrich 1987). All underwent 
significant mass gains in $\mathrm{CO}_{2}, \mathrm{~S}, \mathrm{~K}_{2} \mathrm{O}, \mathrm{Ba}, \mathrm{As}, \mathrm{W}$ (Fig. 9). Thus, the alteration and mineralization of the host rocks, and the formation of the three styles of gold mineralization, occurred under the same hydrothermal fluid system.

The relative chronology between mineralization and deformation can be determined from textural relationships. In fuchsite-carbonate ultramafic rock, gold-rich drill core intervals are characterized by strongly deformed quartz-carbonate veins, which are folded and transposed parallel to $\mathrm{S}_{2}$. This suggests that mineralization was emplaced either pre- or syn- $\mathrm{S}_{2}$ cleavage. In Fe-rich tholeiitic basalts, $\mathrm{S}_{2}$ wraps around pyrite grains that are surrounded by strain shadows filled by alteration minerals, whereas other pyrite grains truncate $\mathrm{S}_{2}$ and contain inclusions of sericite and ankerite. Pyrite growth therefore both predates and postdates the formation of the foliation and the crystallization of other alteration minerals. Because gold is associated with pyrite as inclusions and as discrete grains along pyrite grain boundaries (Fig.11d,e), mineralization is therefore interpreted as a prolonged event that spanned the development of the $\mathrm{S}_{2}$ cleavage along the LLCDZ (Lafrance 2015).

The Kerr-Addison mine is located $6 \mathrm{~km}$ to the east and along strike of the Cheminis mine (Fig. 2). It is hosted by the same altered komatiite and Fe-rich tholeiitic basalt. Hydrothermal alteration is characterized by major gains in $\mathrm{CO}_{2}$, variable gains in $\mathrm{Na}_{2} \mathrm{O}, \mathrm{K}_{2} \mathrm{O}, \mathrm{CaO}$, and strong additions in metals including As, Sb, W (Kishida and Kerrich 1987). These mass changes occurred during the alteration of komatiite to green fuchsite-carbonate schist (carbonate ore) and during the alteration of Fe-rich tholeiitic basalt to a bleached and foliated carbonate-chloritequartz-sericite-albite rock (flow ore), containing gold associated with disseminated pyrite (Thompson 1941; Kishida and Kerrich 1987; Smith et al. 1993). These mineralogical and geochemical changes are very similar to those observed at the Cheminis mine, and thus strongly 
suggest that the two deposits have the same mineralization and alteration history. The KerrAddison mine has two other ore types: graphitic ore and albitite dike ore (Smith et al. 1993). The graphitic ore is hosted in sheared graphitic metasedimentary horizons occurring in Fe-rich tholeiitic basalt. It also occurs along the late, post-ore, Kerr Fault as entrained fragments of mineralized flow ore and broken quartz veins surrounded by a graphitic fault matrix (Smith et al. 1993). The albitite dike ore is hosted by a swarm of mafic albitite dikes. Gold is associated with pyrite, which is present along fractures and in quartz-carbonate veins that cut across the dikes (Smith et al. 1993). The dikes are locally strongly deformed, but they also overprint the foliation in the green fuchsite-carbonate schist and contain mineralized vein fragments of quartz-pyrite and carbonate-pyrite, suggesting that they were emplaced as intramineral dikes during deformation and mineralization (Smith et al. 1993). The swarm of albitite dikes is thought to be associated with a deeper parent intrusive body that provided magmatic hydrothermal fluids to the ore-forming hydrothermal system (Smith et al. 1993).

On an extended trace element diagram normalized to primitive mantle, syenite dikes at Cheminis show strong enrichment in the more incompatible trace elements and pronounced negative $\mathrm{Nb}$, Ta, P, Ti, Sc anomalies (Fig. 12a). Their trace element patterns overlap with those of syenite dikes from Kirkland Lake (Fig. 12a) and albitite dikes from Kerr Addison (Fig. 12b). Because the dikes at Cheminis are similar in composition to the albitite dikes at Kerr Addison, their presence suggests that hydrothermal magmatic fluids may also have contributed to the formation of the Cheminis deposit. The dikes have a weak foliation which is parallel to the $\mathrm{S}_{2}$ cleavage in the surrounding incompetent ultramafic rocks, suggesting that they were emplaced either before or during the formation of the cleavage. If the dikes were emplaced during the formation of the cleavage, then magmatic hydrothermal fluids may have contributed to the 
auriferous hydrothermal fluid system because textural relationships indicate that gold was emplaced during the formation of the cleavage. However, as only three syenite dikes have been mapped in the Cheminis mine area, magmatic hydrothermal fluids, if any, were only a minor component of the hydrothermal fluid system.

Hamilton and Hodgson (1984), Hodgson and Hamilton (1989), Hodgson et al. (1991), and Smith et al. (1993) suggested that gold at Kerr Addison was emplaced along the LLCDZ during the development of a late cleavage. Although they refer to this cleavage as $S_{2}$, it overprints an older cleavage, and it therefore correlates with the overprinting $\mathrm{S}_{3}$ cleavage at Cheminis. This is later during the evolution of the LLCDZ than reported here for the Cheminis mine, where gold is interpreted to have been emplaced during the development of the $\mathrm{S}_{2}$ cleavage. Thus, if their interpretation is correct, then gold could have been deposited over a period spanning both $\mathrm{D}_{2}$ and $\mathrm{D}_{3}$ deformation events. However, from east to west across Ontario, all deposits plunge parallel to the $\mathrm{L}_{2}$ stretching lineation, including the McBean, Anoki, Upper Canada, as well as the Cheminis and Kerr Addison - Chesterville deposits (Wilkinson et al. 1999; Ispolatov et al. 2008), suggesting that mineralization was emplaced early during the $\mathrm{D}_{2}$ evolution of the LLCDZ. Further evidence of the early timing of gold mineralization is the presence at Kerr Addison of komatiites with undeformed spinifex textures that are completely altered to fuchsite and carbonate (Kishida and Kerrich 1987; Smith et al. 1993). An example of the transition from the latter (Fig. 13a) to fuchsite-carbonate schist (Fig. 13b) can be seen in drill core. This suggests that hydrothermal alteration occured early and locally predated ductile deformation along the LLCDZ.

Early hydrothermal alteration and coeval emplacement of gold during crustal extension and deposition of the Timiskaming Group in an extensional basin has been postulated by 
Cameron (1993) and more recently invoked by Bleeker (2012). The LLCDZ may have originated as an early syn-depositional normal fault constraining the Timiskaming basin to the south (Dimroth et al. 1982; Cameron 1993; Mueller et al. 1994; Bleeker 2012). During crustal extension, upwelling followed by decompression and partial melting of the mantle produced alkaline magmas that were emplaced in the basin as flows, volcaniclastic rocks and intrusions (Cameron 1993). The alkaline magma migrated along the basin-bounding LLCDZ, which may also have acted as a conduit for the upward migration of gold-bearing hydrothermal fluids (Cameron 1993, Bleeker 2012). Early hydrothermal alteration of the spinifex-textured komatiite and the formation of $F_{1}$ folds possibly occurred during this early extensional event. A link between crustal extension, the deposition of clastic sediments, and gold mineralization has also been suggested for the Red Lake greenstone belt in the western Superior Province (Calvert et al. 2004). During subsequent basin inversion and shortening, the LLCDZ was reactivated as a reverse fault (Hodgson and Hamilton 1989; Cameron 1993; Bleeker 2012). The movement along the fault is generally thought to be south-over-north in the Ontario segments of the fault (Thompson et al. 1950; Hodgson et al. 1991; Cameron 1993; Smith et al. 1993; Ispolatov et al. 2005, 2008; Bleeker 2012; Zhang et al. 2014; this study) and north-over-south in the Quebec segments of the fault (Camiré and Burg 1993; Daigneault et al. 2002). The gold deposits along the LLCDZ, including the Cheminis and Kerr Addison - Chesterville deposits, formed during this contractional $\mathrm{D}_{2}$ event as hydrothermal fluids were channelized and migrated upward along the fault (Card et al. 1989; Hodgson and Hamilton 1989; Cameron 1993; this study). The LLCDZ was subsequently reactivated as a late dextral transcurrent fault (Hamilton and Hodgson 1984; Toogood and Hodgson 1985; Robert 1989; Smith et al. 1993; this study) but with few 
exceptions (Neumayr et al. 2000, 2007; Bédeaux et al. 2014), this last movement on the fault does not appear to have contributed significantly to its gold endowment.

\section{Conclusions}

From Larder Lake to the Ontario-Quebec provincial border, the LLCDZ formed by partitioning of the $\mathrm{D}_{2}$ deformation along a band of mafic and ultramafic rocks of the Larder Lake Group, following regional folding of the Timiskaming turbidites $(<$ ca.2674 Ma) and imbrication of these rocks with the older Larder Lake volcanic rocks (ca. $2705 \mathrm{Ma}$ ). The $\mathrm{D}_{2}$ deformation (ca. $2672 \mathrm{Ma}$ - ca. $2665 \mathrm{Ma}$ ) produced the strong $\mathrm{S}_{2}$ foliation and $\mathrm{L}_{2}$ stretching lineation that characterize the LLCDZ.

Gold was emplaced during $\mathrm{D}_{2}$ south-side-up ductile shear along the LLCDZ. The styles of gold mineralization at the Cheminis mine differ according to their host rocks, but they have similar alteration mineralogy (sericite/fuchsite, carbonate, chlorite, albite, pyrite, arsenopyrite) and underwent similar mass gains in $\mathrm{CO}_{2}, \mathrm{~S}, \mathrm{~K}_{2} \mathrm{O}, \mathrm{As}, \mathrm{W} \pm \mathrm{CaO}, \mathrm{Na}_{2} \mathrm{O}, \mathrm{Sb}$, suggesting that they interacted with the same hydrothermal fluids. Hydrothermal alteration minerals have higher Mg number in the mineralized host rocks than in their least altered precursors. Thus, detailed mapping of alteration mineral assemblages and their mineral chemistries could be an important vectoring tool to mineralization. Mineral exploration should focus on segments of the LLCDZ with pronounced $\mathrm{S}_{2}$ and $\mathrm{L}_{2}$ fabrics and well developed south-side-up shear sense indicators, because these segments underwent higher strain and were likely more permeable to upward migrating hydrothermal fluids. 


\section{Acknowledgements}

Don Lavigne, François Viens, and Jeff Cormier are thanked for providing access to the Cheminis mine site. The work benefited from discussions with Vladimir Ispolatov, Benoît Dubé, and John Ayer. Kate Rubingh reviewed an early draft of the paper. Sébastien Castonguay, Réal

Daigneault, Michel Jébrak and Stéphane Perrouty are thanked for their reviews and Kathy Bethune for her editorial comments. Funding was provided by a NSERC Discovery grant to B. Lafrance. 


\section{References}

Ayer, J.A., Ketchum, J.W.F., Trowell, N.F., 2002. New geochronological and neodymium isotopic results from the Abitibi greenstone belt, with emphasis on the timing and the tectonic implications of Neoarchean sedimentation and volcanism. In Summary of Field Work and Other Activities 2002, Ontario Geological Survey, Open File Report 6100, 5-1 5-16.

Ayer, J.A., Thurston, P.C., Bateman, R., Dubé, B., Gibson, H.L., Hamilton, M.A., Hathway, B., Hocker, S.M., Houlé, M.G., Hudak, G., Ispolatov, V.O., Lafrance, B., Lesher, C.M., MacDonald, P.J., Péloquin, A.S., Piercey, S.J., Reed, L.E., Thompson, P.H., 2005. Overview of results from the greenstone architecture project: Discovery Abitibi initiative. Ontario Geological Survey, Open File Report 6154, 146 pp.

Bédeaux, P., Pilote, P., Daigneault, R., Rafini, S., 2014. Synthesis of the structural evolution and associated gold mineralization of the Cadillac Fault, Abitibi, Canada. Geological Society of America, 2014 Annual Meeting \& Exposition, Abstracts with Programs, Vancouver, Canada.

Bleeker, W., 2012. Targeted Geoscience Initiative 4. Lode gold deposits in ancient deformed and metamorphosed terranes: The role of extension in the formation of Timiskaming basins and large gold deposits, Abitibi greenstone belt - a discussion. In Summary of Field Work and Other Activities 2012, Ontario Geological Survey, Open File Report 6280, 47-1 - 4712.

Calvert, A.J., Cruden, A.R., Hynes, A., 2004. Seismic evidence for preservation of the Archean Uchi granite-greenstone belt by crustal-scale extension. Tectonophysics 388, 135-143.

Cameron, E.I, 1993. Precambrian gold: perspectives from the top and bottom of shear zones. The Canadian Mineralogist 31, 917-944.

Camiré, G.E., Burg, J.-P., 1993. Late Archean thrusting in the northwestern Pontiac Subprovince, Canadian Shield. Precambrian Research 61, 51-66.

Card, K.D., Poulsen, K.H., Robert, F., 1989. The Archean Superior Province of the Canadian Shield and its lode gold deposits. In The Geology of Gold Deposits: the Perspective in 1988. Edited by R.R. Keays, W.R.H. Ramsay, D.I. Groves. Economic Geology Monograph 6, pp. 19-36.

Corfu, F., Jackson, S.J., Sutcliffe, R.H., 1991. U-Pb ages and tectonic significance of Late Archean alkali magmatism and nonmarine sedimentation: Timiskaming Group, southern Abitibi belt, Ontario. Canadian Journal of Earth Sciences 28, 489-503.

Corfu, F., Krogh, T.E., Kwok, Y.Y., Jensen, L.S., 1989. U-Pb zircon geochronology in the southwestern Abitibi greenstone belt, Superior Province. Canadian Journal of Earth Sciences 26, 1747-1763.

Daigneault, R., Mueller, W.U., Chown, E.H., 2002. Oblique Archean subduction: accretion and exhumation of an orogenic arc during dextral transpression, Southern Volcanic Zone, Abitibi Subprovince Canada. Precambrian Research 115, 261-290.

Dimroth, E., Imreh, L., Rocheleau, M., Goulet, N., 1982. Evolution of the south-central part of the Archean Abitibi belt, Quebec. Part I: Stratigraphy and paleogeographic model. Canadian Journal of Earth Sciences 19, 1729-1758.

Dubé, B., Gosselin, P., 2007. Greenstone-hosted quartz-carbonate vein deposits. In Mineral Deposits of Canada: A Synthesis of Major Deposit Types, District Metallogeny, the Evolution of Geological Provinces, and Exploration Methods. Edited by W.D. Goodfellow. 
Geological Association of Canada, Mineral Deposits Division, Special Publication 5, pp. 49-73.

Grant, J.A., 1986. The icogon diagram - a simple solution to Gresen's equation for metasomatic alteration. Economic Geology 81, 1976-1982.

Hamilton, J.V., Hodgson, C.J., 1984. Structural geology and gold mineralization in the Kirkland Lake - Larder Lake Deformation Zone. In Summary of Field Work 1984, Ontario Geological Survey, Miscellaneous Paper 119, 220-225.

Hodgson, C.J., Hamilton, J.V., 1989. Gold mineralization in the Abitibi greenstone belt: rndstage results of Archean collisional tectonics? In The Geology of Gold Deposits: the Perspective in 1988. Edited by R.R. Keays, W.R.H. Ramsay, D.I. Groves. Economic Geology Monograph 6, pp. 86-100.

Hodgson, C.J., Hamilton, J.V., Guimond, R.P., 1991. Relationship between gold deposits and the tectonic framework of the Abitibi Greenstone Belt in the Kirkland Lake - Larder Lake area. Ontario Geological Survey, Open File Report 5782, 60 pp.

Hyde, R.S., 1980. Sedimentary facies in the Archean Timiskaming Group and their tectonic implications, Abitibi greenstone belt, northeastern Ontario, Canada. Precambrian Research 12, 161-195.

Ispolatov, V., Lafrance, B., Dubé, B., Hamilton, M., Creaser, R., 2005. Geology, structure, and gold mineralization, Kirkland Lake and Larder Lake areas (Gauthier and Teck townships): Discovery Abitibi initiative. Ontario Geological Survey, Open File Report 6159, 170 pp.

Ispolatov, V., Lafrance, B., Dubé, B., Creaser, R., Hamilton, M., 2008. Geologic and structural setting of gold mineralization in the Kirkland Lake-Larder Lake gold belt, Ontario.

Economic Geology 103, 1309-1340.

Jensen, L.S., Langford, F.F., 1985. Geology and petrogenesis of the Archean Abitibi belt in the Kirkland Lake area, Ontario. In Ontario Geological Survey, Miscellaneous Paper 123, 130 p.

Jensen, L.S., Pyke, D.R., 1982. Komatiites in the Ontario portion of the Abitibi belt. In Komatiites. Edited by N.T. Arndt and E.G. Nisbet. George Allen and Unwin Ltd., London, 147-157.

Kishida, A., Kerrich, R.,1987. Hydrothermal alteration zoning and gold concentration at the Kerr-Addison Archean lode gold deposit, Kirkland Lake, Ontario. Economic Geology 82, 649-690.

Lafrance, B., 2015. Structural and lithological controls on gold mineralization at the Cheminis mine: Implications for the formation of gold deposits along the Larder Lake - Cadillac deformation zone, Ontario. In Targeted Geoscience Initiative 4: Contributions to the Understanding of Precambrian Lode Gold Deposits and Implications for Exploration. Edited by B. Dubé and P. Mercier-Langevin. Geological Survey of Canada, Open File 7852, pp. 49-54.

Lin, S., Jiang, D., Williams, P.F., 1998. Transpression (or transtension) zones of triclinic symmetry: natural examples and theoretical modeling. In Continental Transpressional and Transtensional Tectonics. Edited by R.E. Holdsworth, R.A. Strachan, J.F. Dewey. Geological Society (of London), Special Publication 135, pp. 41-57.

Mueller, W., Donaldson, J.A., Doucet, P., 1994. Volcanic and tectono-plutonic influences on sedimentation in the Archean Kirkland Basin, Abitibi greenstone belt, Canada.

Precambrian Research 68, 201-230. 
Neumayr, P., Hagemann, S.G., Couture, J.-F., 2000. Structural setting, textures, and timing of hydrothermal vein systems in the Val d'Or camp, Abitibi, Canada: implications for the evolution of transcrustal, second- and third-order fault zones and gold mineralization. Canadian Journal of Earth Sciences 37, 95-114.

Neumayr, P., Hagemann, S.G., Banks, D.A., Yardley, B.W.D., Couture, J.-F., Landis, G.P., Rye, R., 2007. Fluid chemistry and evolution of hydrothermal fluids in an Archean transcrustal fault zone network: the case of the Cadillac Tectonic Zone, Abitibi greenstone belt, Canada. Canadian Journal of Earth Sciences 44, 745-773.

Pilote, P., Daigneault, R., David, J., and McNicoll, V., 2014. Architecture of the Malartic, Piché and Cadillac groups and the Cadillac Fault, Abitibi: Geological revision, new dates and interpretations. Québec Mines 2014, Abstracts of Oral Presentations and Posters, http://quebecmines.gouv.qc.ca/2014/documents/resume_conference_2014_en.pdf

Poulsen, K.H., Robert, F., and Dubé, B., 2000. Geological Classification of Canadian Gold Deposits; Geological Survey of Canada, Bulletin 540, 106 p.

Robert, F., 1989. Internal structure of the Cadillac tectonic zone southeast of Val d'Or, Abitibi greenstone belt, Quebec. Canadian Journal of Earth Sciences 26, 2661-2675.

Robin, P.-Y., Cruden, A.R., 1994. Strain and vorticity patterns in ideally ductile transpression zones. Journal of Structural Geology 16, 447-466.

Sanderson, D.J., Marchini, W.R.D., 1984. Transpression. Journal of Structural Geology 6, 449458.

Smith, J.P., Spooner, E.T.C., Broughton, D.W., Ploeger, F.R., 1993. Archean Au-Ag-(W) quartz vein/disseminated mineralisation within the Larder Lake - Cadillac Break, Kerr Addison Chesterville system, North East Ontario, Canada. Ontario Geological Survey, Open File Report 5831, 309 pp.

Sun, S., and McDonough, W.F. 1989. Chemical and isotopic systematics of oceanic basalts: Implications for mantle compositions and processes. In Magmatism in the Ocean Basins. Edited by A.D. Saunders and M.J. Norry.. Geological Society, Special Publication 42, pp. 313-345.

Thompson, J.E., 1941. Geology of McGarry and McVittie townships, Larder Lake area. Ontario Department of Mines Annual Reports 50 Part VII, 99 pp.

Thompson, J.E., Charlewood, G.H., Griffin, K., Hawley, J.E., Hopkins, H., MacIntosh, C.G., Ogryzlo, S.P., Perry, O.S., Ward, W., 1950. Geology of the main ore zone at Kirkland Lake. Ontario Department of Mines Annual Reports 57 Part V, 54-188.

Toogood, D.J., Hodgson, C.J., 1985. A structural investigation between Kirkland Lake and Larder Lake gold camps. Ontario Geological Survey, Miscellaneous Paper 127, 200-205.

Wilkinson, L., Cruden, A.R., Krogh, T.E., 1999. Timing and kinematics of post-Timiskaming deformation within the Larder Lake-Cadillac deformation zone, southwest Abitibi greenstone belt, Ontario, Canada. Canadian Journal of Earth Sciences 36, 627-647.

Zhang, J., Lin, S., Linnen, R., Martin, R., 2014. Structural setting of the Young-Davidson syenite-hosted gold deposit in the western Cadillac-Larder Lake deformation zone, Abitibi greenstone belt, Superior Province, Ontario. Precambrian Research 248, 39-59. 


\section{Figure captions}

Figure 1: Simplified geological map of the Southern Abitibi subprovinve modified after Poulsen et al. (2000) showing the location of gold deposits along the Destor-Porcupine deformation zone (DPDZ) and the Larder Lake - Cadillac deformation zone (LLCDZ).

Figure 2: Simplified geological map of Larder Lake - Cadillac deformation zone from Kirkland Lake to the Ontario - Quebec provincial border. Modified after Ispolatov et al. (2008).

Figure 3: (a) Ternary Al-Mg-Fe tot $+\mathrm{Ti}$ diagram of Jensen and Pyke (1982). (b) Binary $\mathrm{TiO}_{2} \mathrm{vs} \mathrm{Zr}$ diagram. B, basalt; A, andesite; D, dacite; R, rhyolite; FeB, High-Fe tholeiite basalt; MgB, High-Mg tholeiite basalt.

Figure 4: Trace element plots of syenite dike and sandstone at Cheminis, using normalizing chondrite and primitive mantle values of Sun and McDonough (1989): (a) Rare earth element plot normalized to chondrite. (b) Extended trace element plot normalized to primitive mantle

Figure 5: Geological map of the Cadillac - Larder Lake deformation zone from the Fernland mine to the Cheminis mine. UTM coordinates in NAD83. Contours on stereonet plots are in multiple of random distribution. Number of measurements on the bottom right hand side of stereonet plots.

Figure 6: Photomicrographs of shear sense indicators along the Cadillac - Larder Lake deformation zone. (a) Carbonate in strain shadows around pyrite grains (indicated by arrows) and anticlockwise change in orientation of a S-fabric defined by chlorite, suggesting south-side-up movement. Natural light. (b) Steady-state S-fabric in a quartz vein suggesting south-side-up movement. Crossed polars.

Figure 7: Geological map of the ore zones at the Cheminis mine area. UTM coordinates in NAD83.

Figure 8: Underground, 275 feet, 525 feet, 865 feet map level plans of the Cheminis mine.

Figure 9: Mass change histograms of: (a) Flow ore mineralized Fe-rich tholeiitic basalt relative to least altered precursor. (b) Carbonate ore fuschsite-carbonate ultramafic rock relative to talc-chlorite ultramafic rock. (c) Mineralized sandstone relative to least altered precursor.

Figure 10: $\mathrm{CaO} / \mathrm{Al}_{2} \mathrm{O}_{3}, \mathrm{CO}_{2} / \mathrm{Al}_{2} \mathrm{O}_{3}, \mathrm{MgO} / \mathrm{Al}_{2} \mathrm{O}_{3}$ versus $\mathrm{K}_{2} \mathrm{O} / \mathrm{Al}_{2} \mathrm{O}_{3}$ binary molar diagrams for flow ore, mineralized Fe-rich tholeiitic basalt

Figure 11: Flow ore mineralized Fe-rich tholeiitic basalt along the Cadillac-Larder Lake deformation zone: (a) Drill core photograph of pyrite grains overgrowing $\mathrm{S}_{2}$ foliation (scale bar in $\mathrm{mm}$ ). (b) Natural light photomicrograph of $\mathrm{S}_{2}$ foliation truncated by a pyrite grain with quartz-filled strain shadows. (c) Crossed polar photomicrograph of a pyrite grain with carbonate inclusions and quartz-carbonate in strain shadow. (d) Backscattered 
scanning electron microscope image of a pyrite grain with gold inclusions. (e) Backscattered scanning electron microscope image of a gold grain along pyrite grain boundary. (f) Backscattered scanning electron microscope image of gold and covellite in a late fracture cutting across pyrite grain.

Figure 12: Extended trace element diagrams normalized to primitive mantle comparing the trace element composition of syenite dikes at Cheminis to that of (a) syenite porphyry and mafic syenite at Kirkland Lake after Ispolatov et al. (2008), and (b) albitite dike at the KerrAddison mine after Smith et al. (1993).

Figure 13: Drill core photographs of (a) altered, undeformed, spinifex-textured komatiite cut by a quartz-carbonate vein with fuchsitic selvedges at the Kerr Addison mine, and (b) altered, deformed, fuchsite-carbonate ultramafic rock at the Kerr Addison mine. The drill cores are from collections of the Ontario Geological Survey regional office in Kirkland Lake.

Table 1: Representative whole rock geochemical analyses

Table 2: Representative SEM mineral analyses 


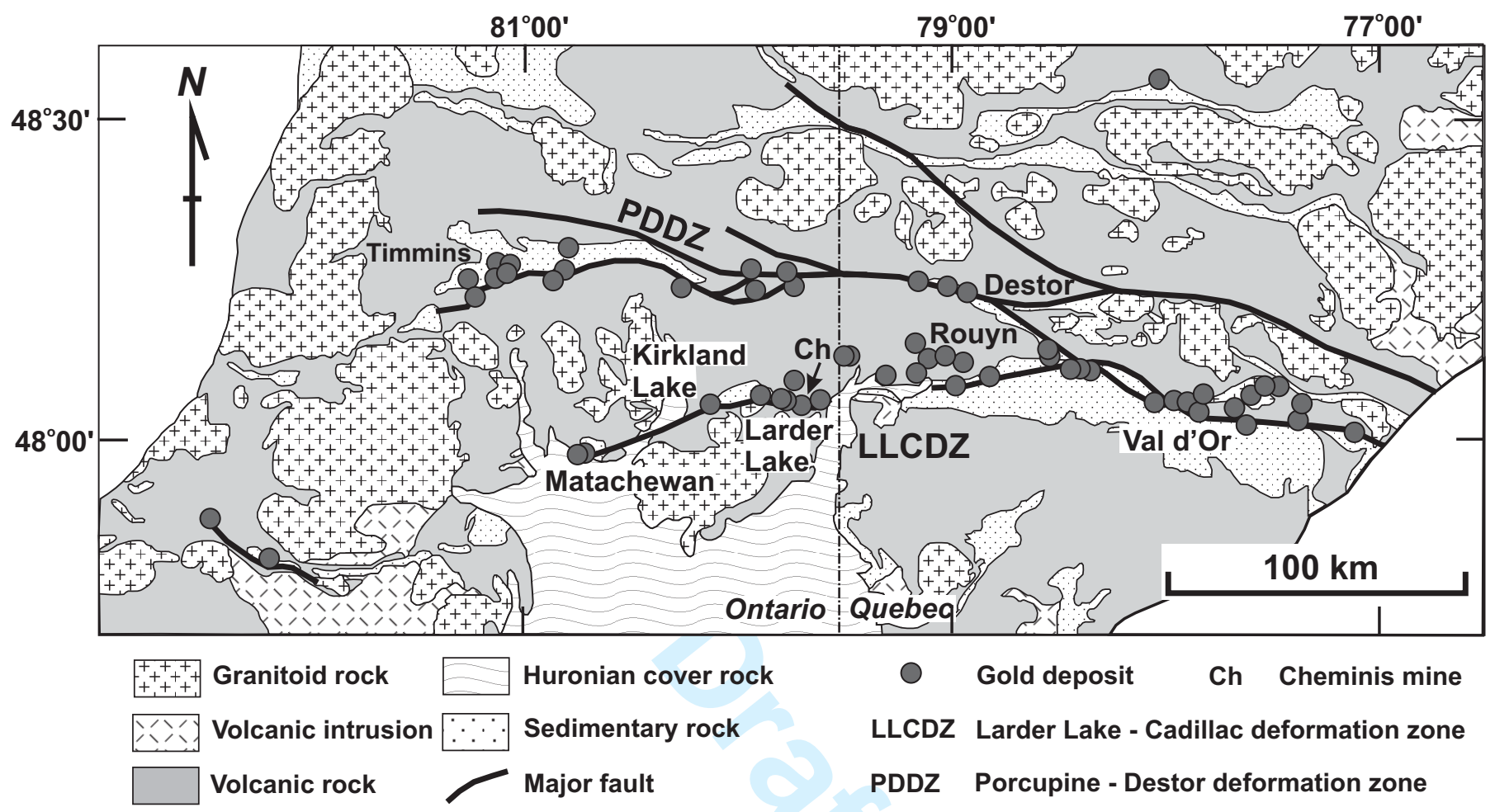

Figure 1: Lafrance 


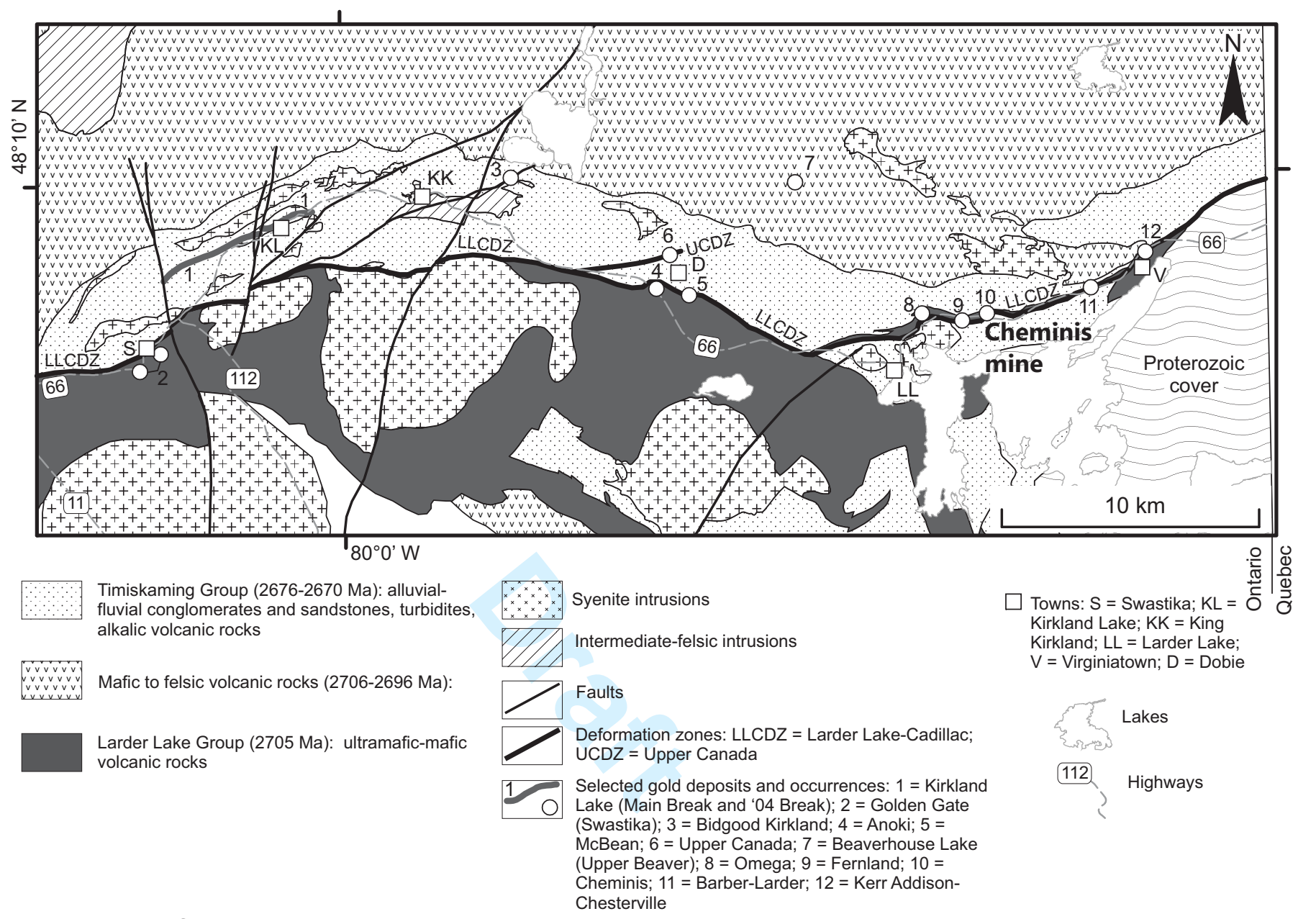

Figure 2: Lafrance 


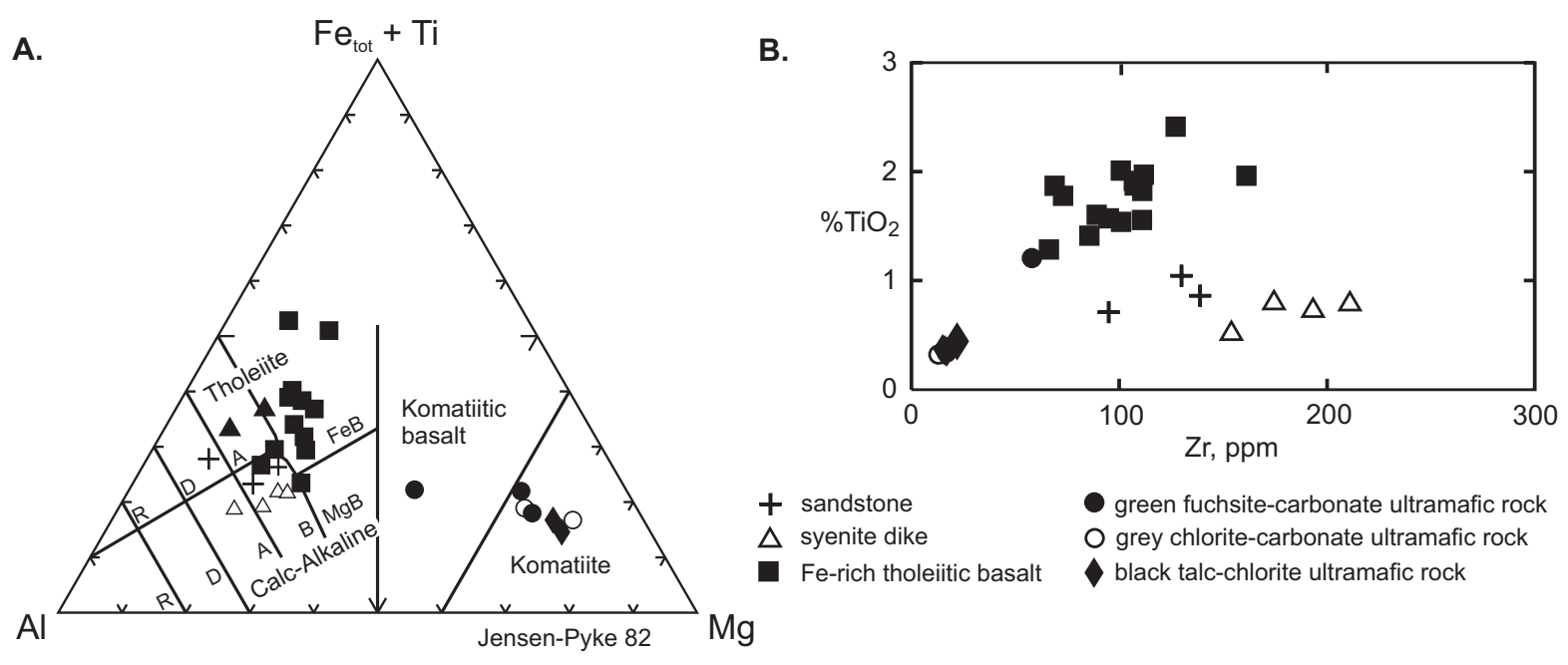

Figure 3: Lafrance 

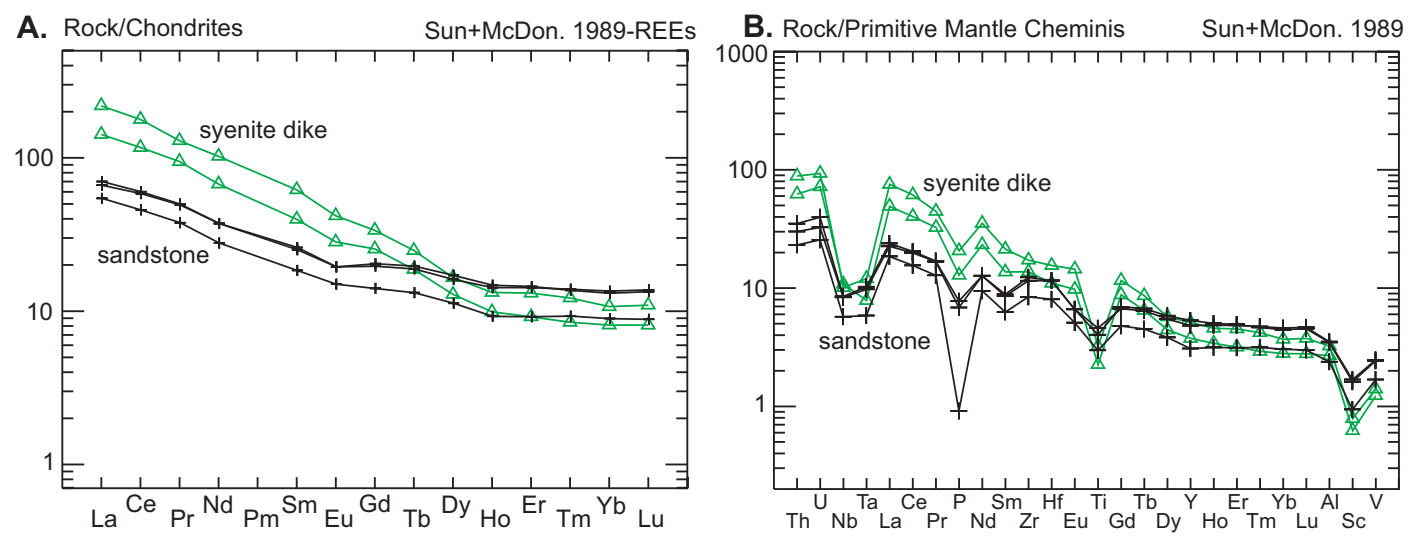

Figure 4: Lafrance 


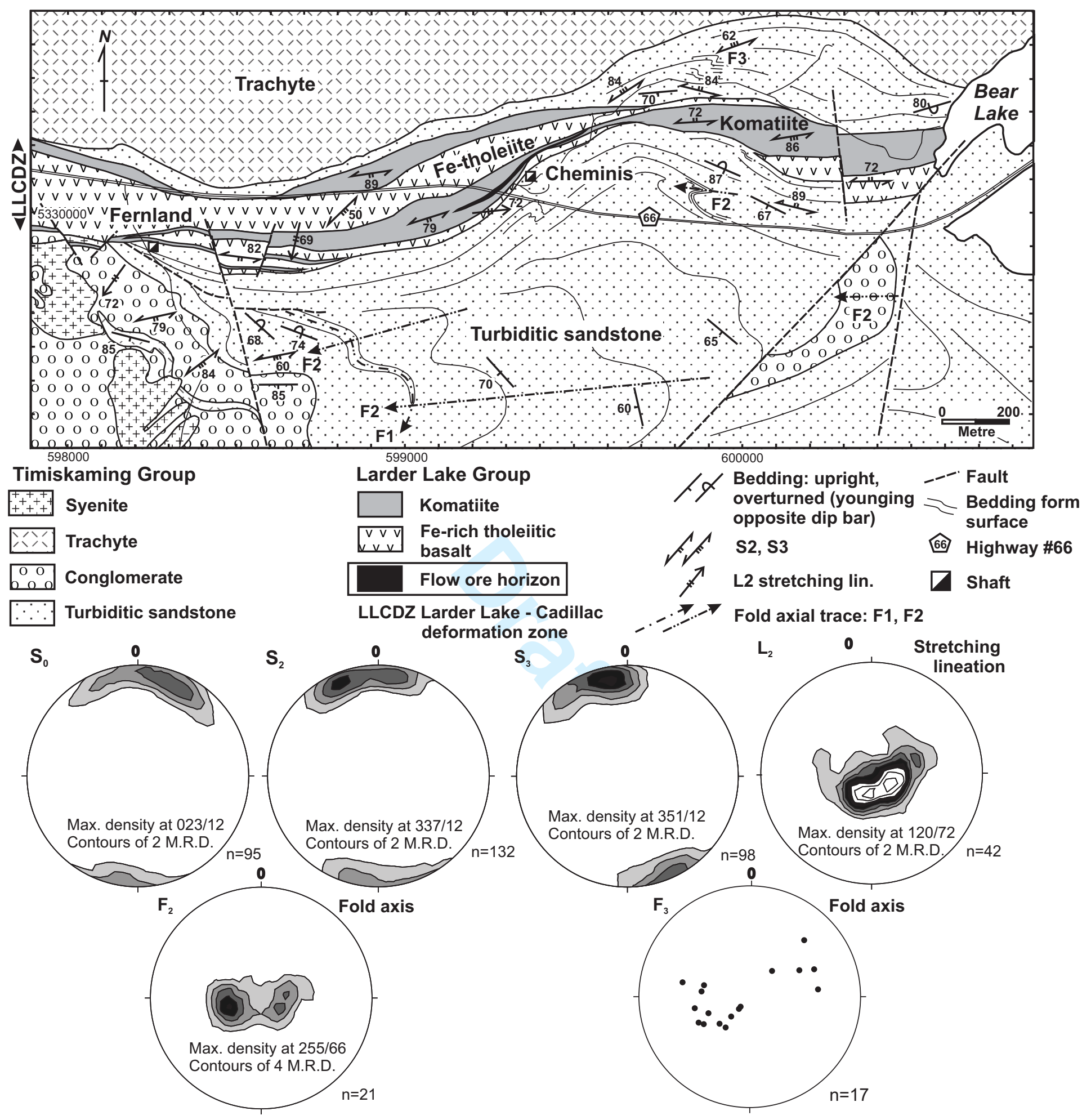

Figure 5: Lafrance 

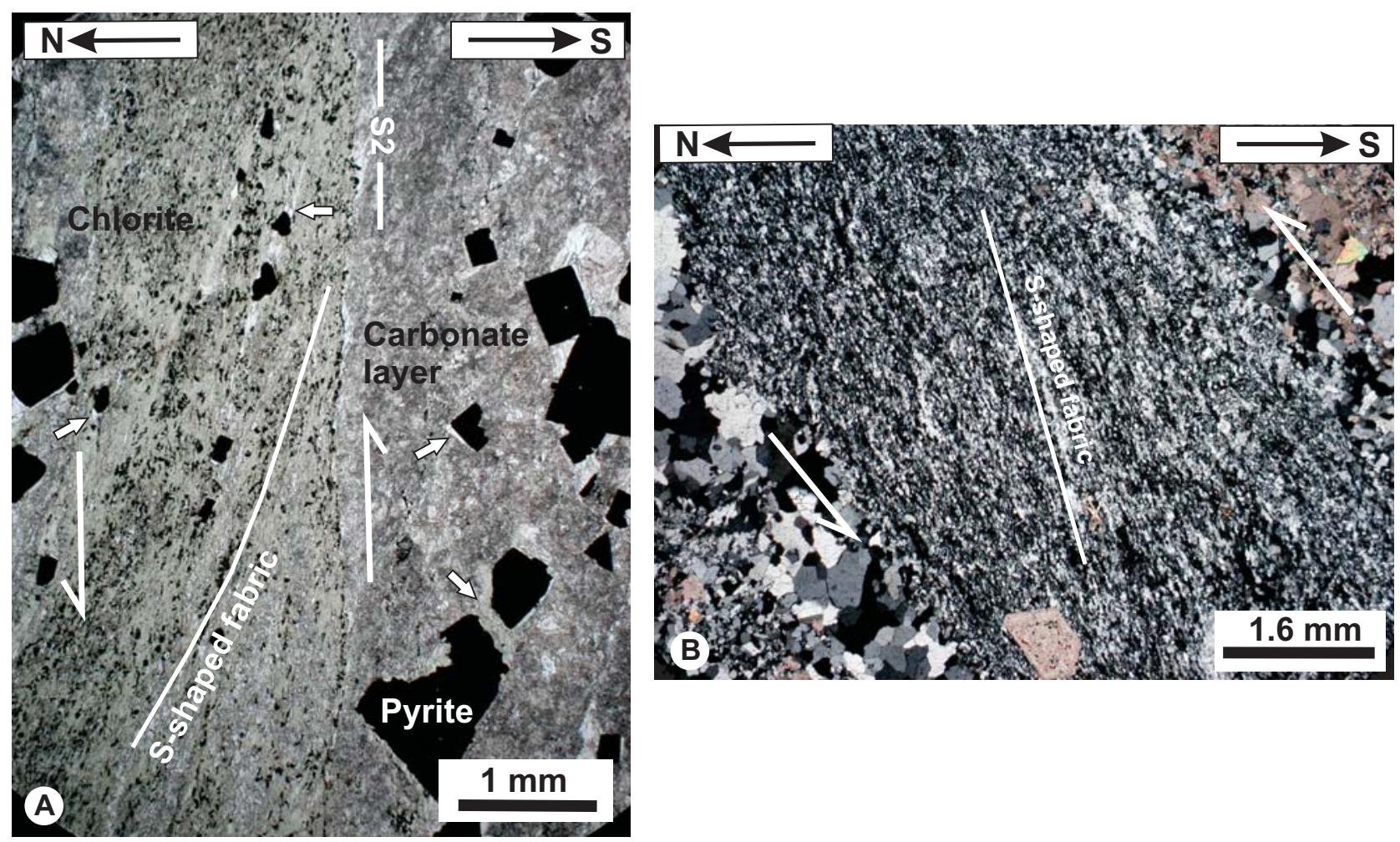

Figure 6: Lafrance 


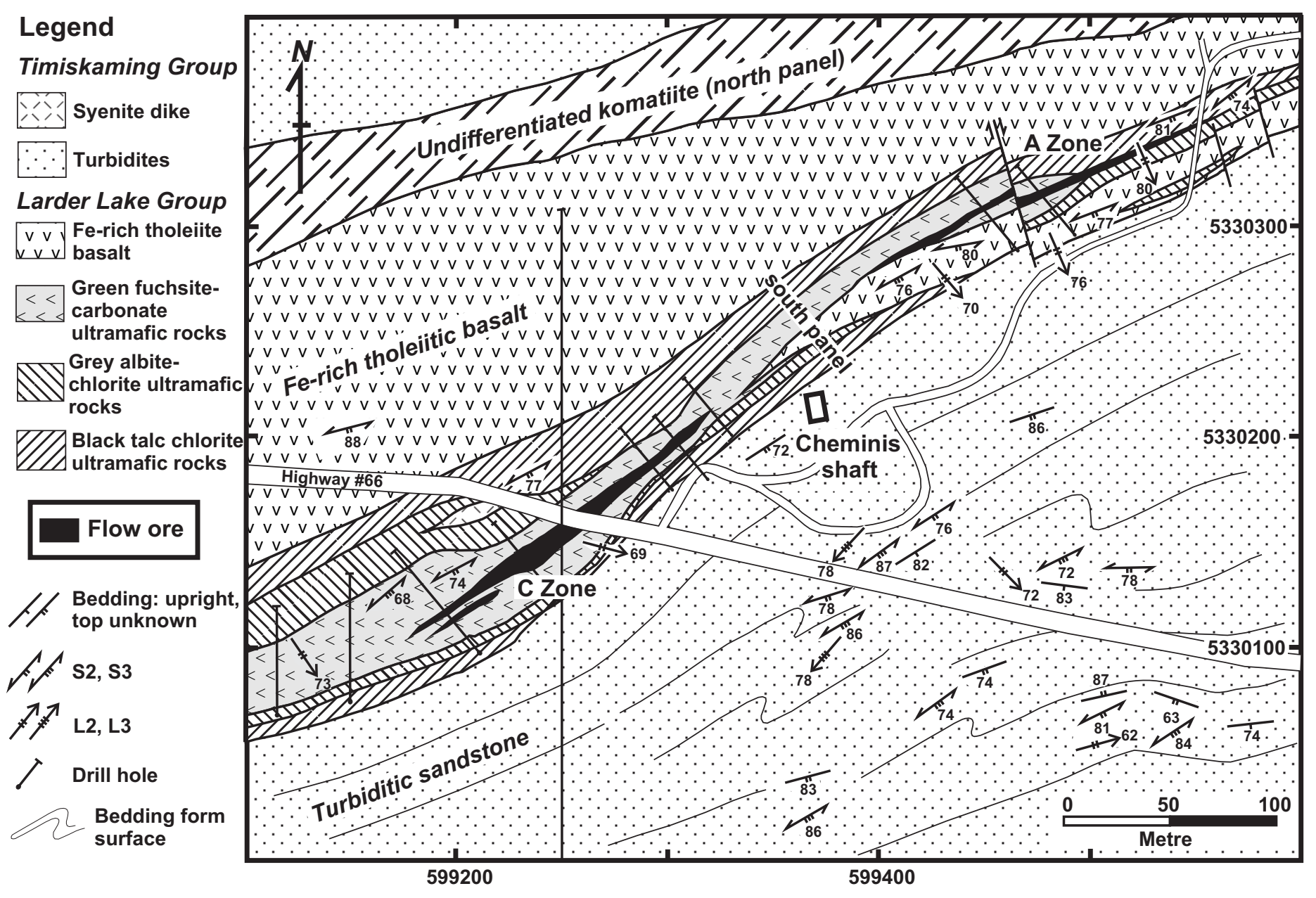

Figure 7: Lafrance 


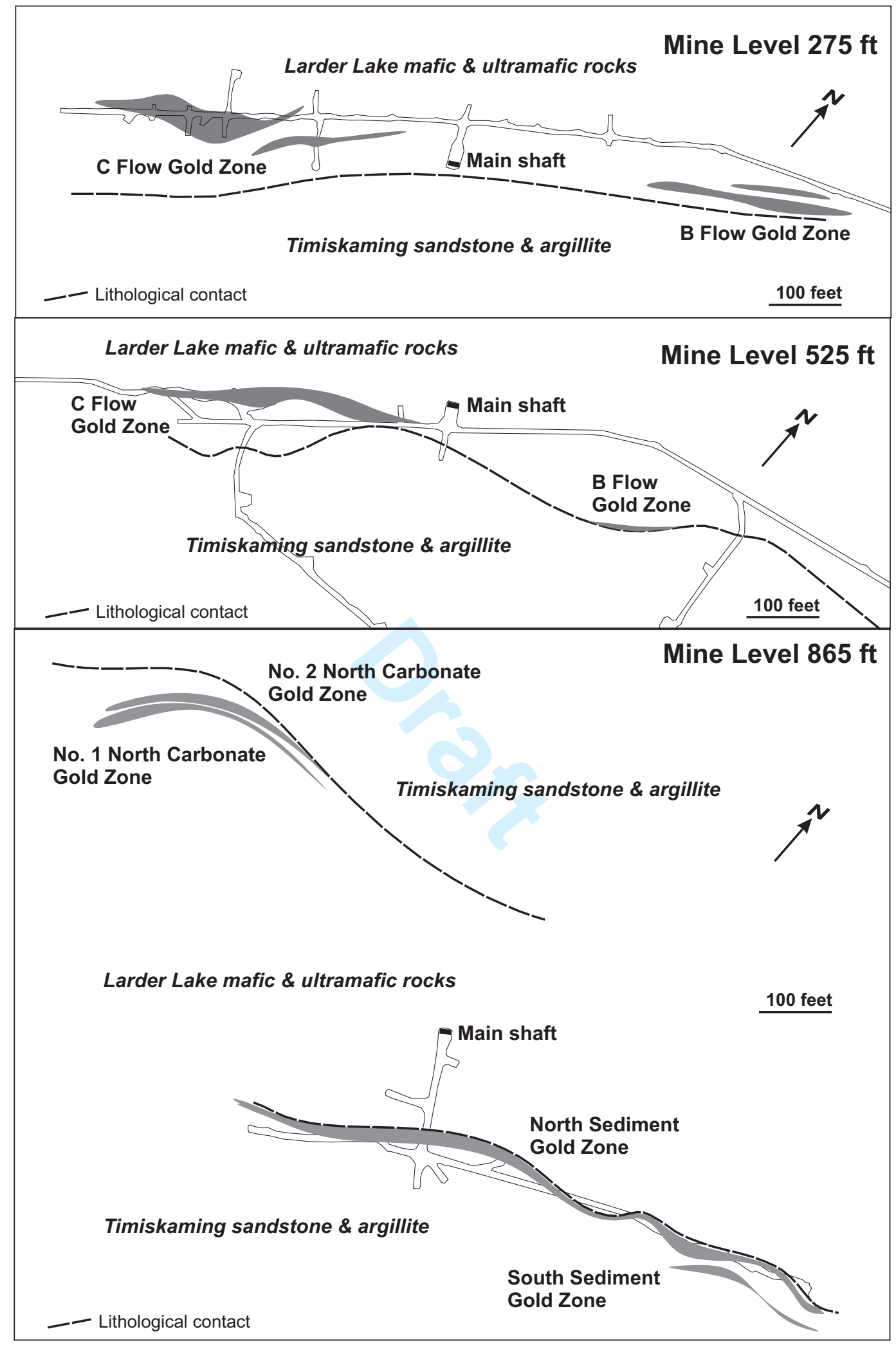

Figure 8: Lafrance 
A. Flow ore Zone in Fe-rich tholeiitic basalt

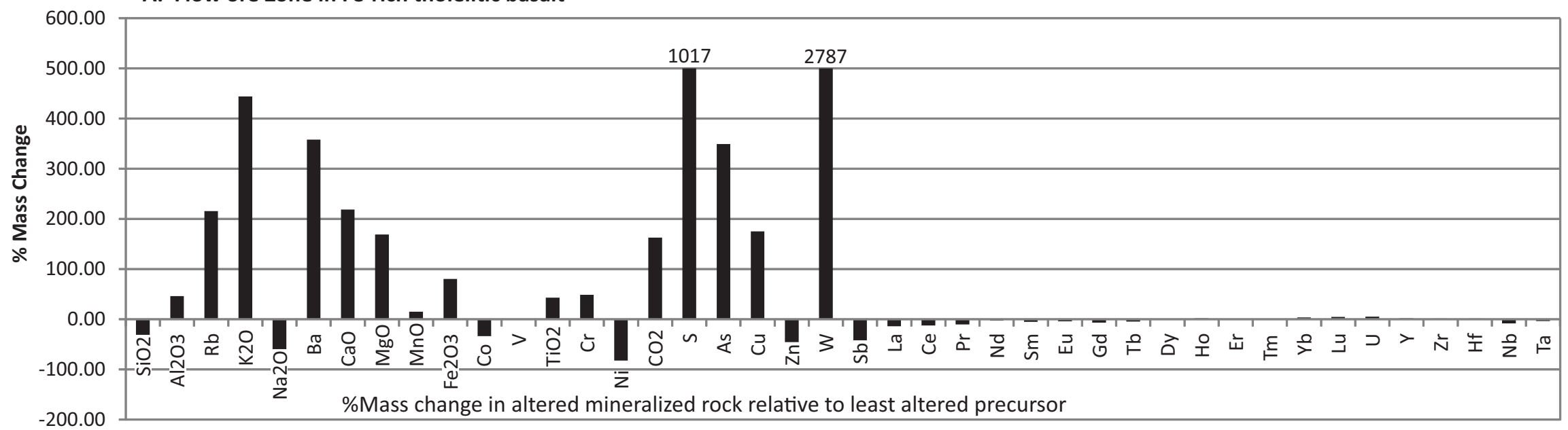

B. Ultramafic-hosted mineralization (carbonate ore)

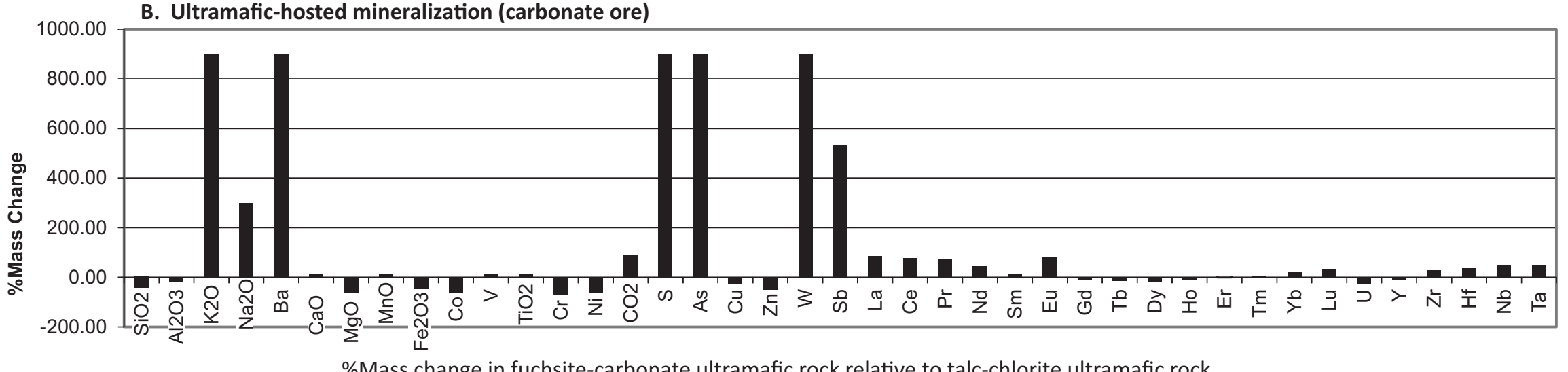

\%Mass change in fuchsite-carbonate ultramafic rock relative to talc-chlorite ultramafic rock

C. Sandstone-hosted mineralization

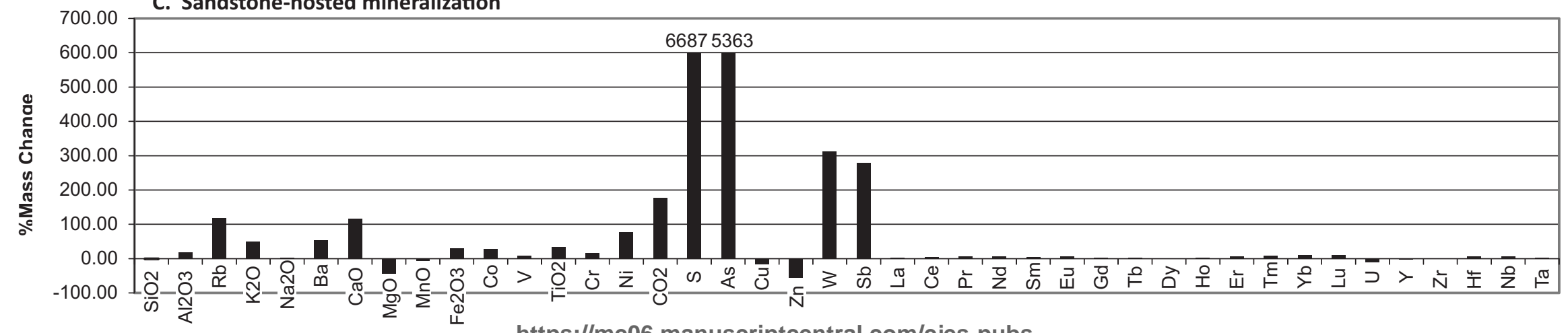

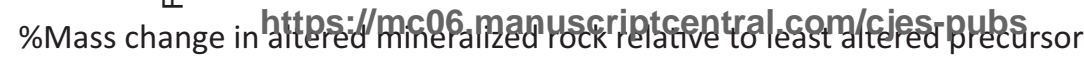

Figure 9: Lafrance 

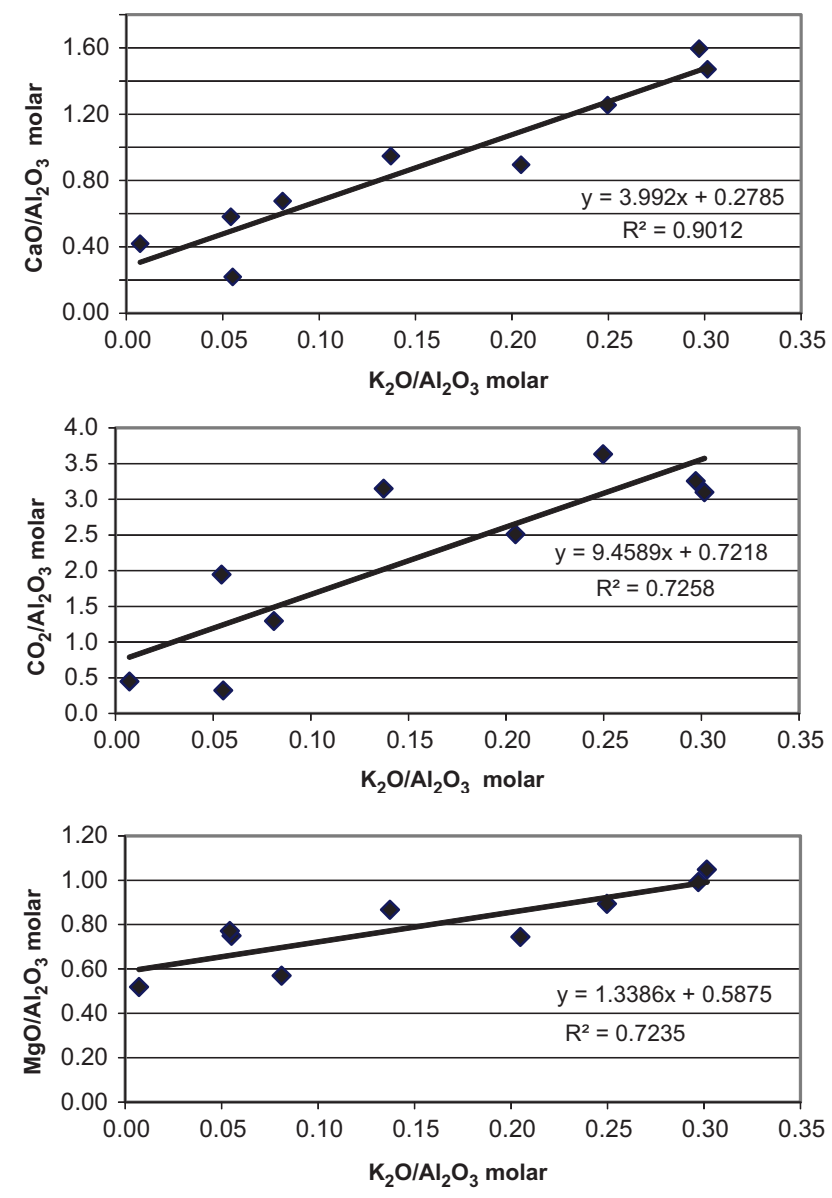

Figure 10: Lafrance 

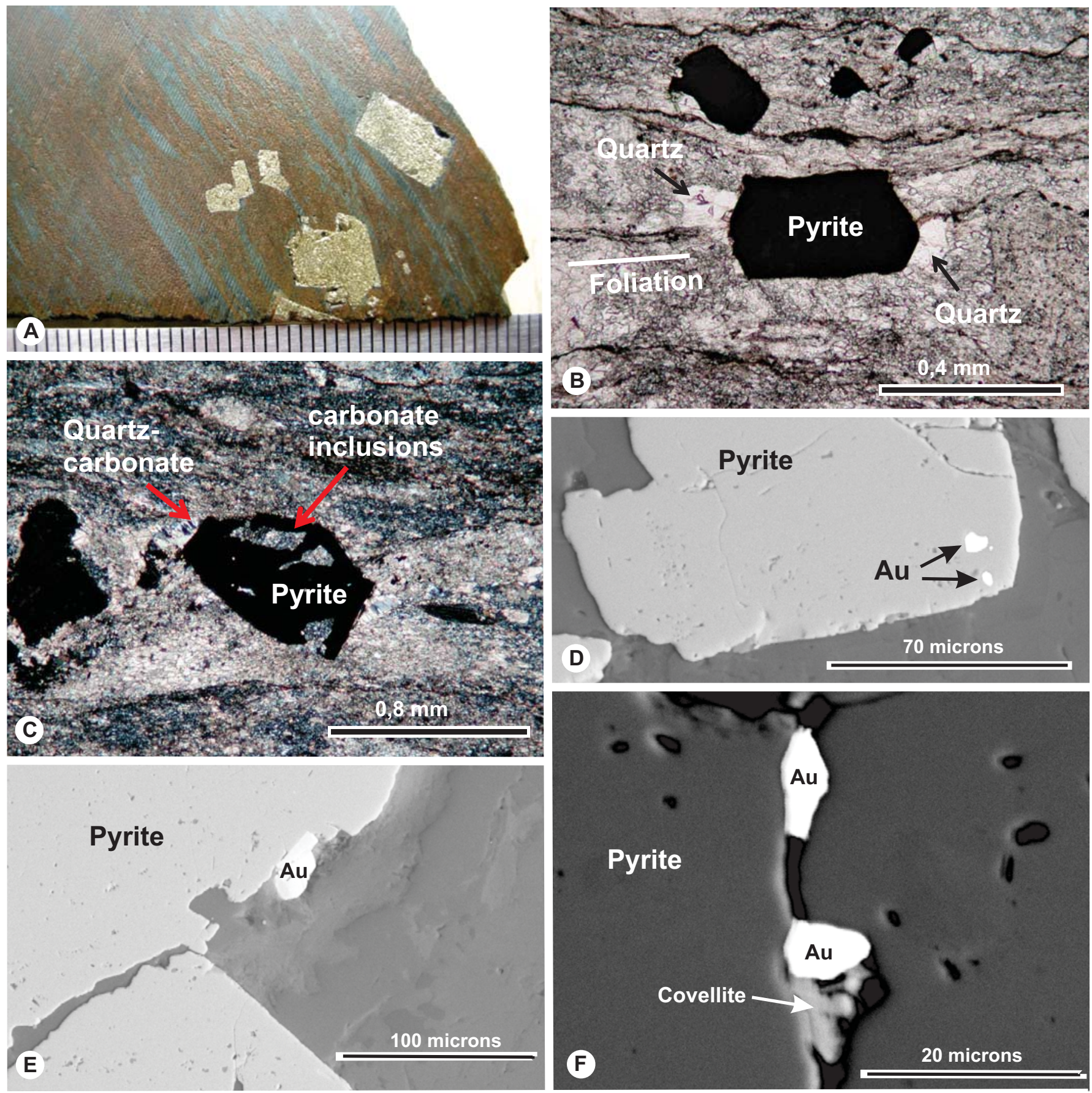

Figure 11: Lafrance 
A.

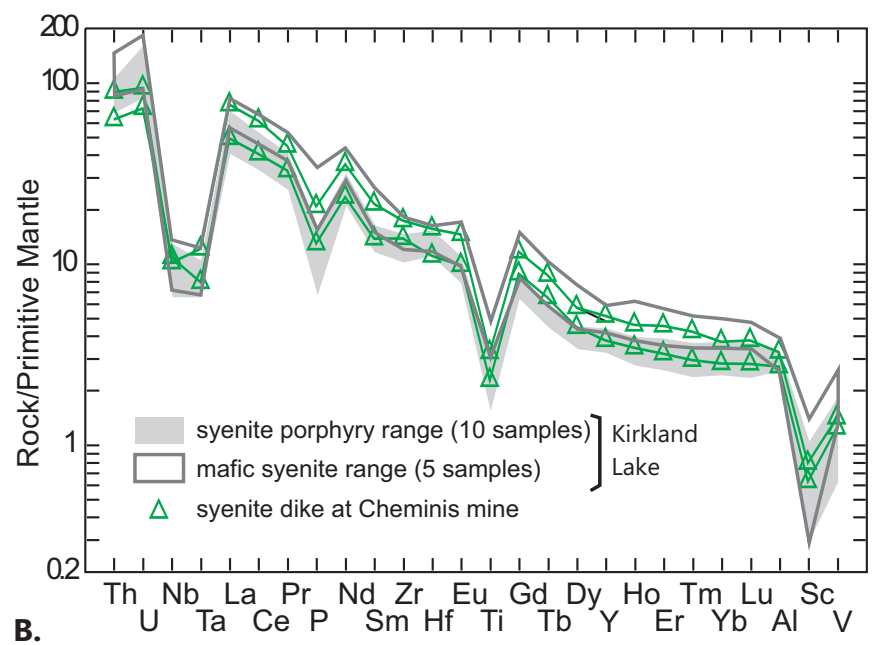

B.

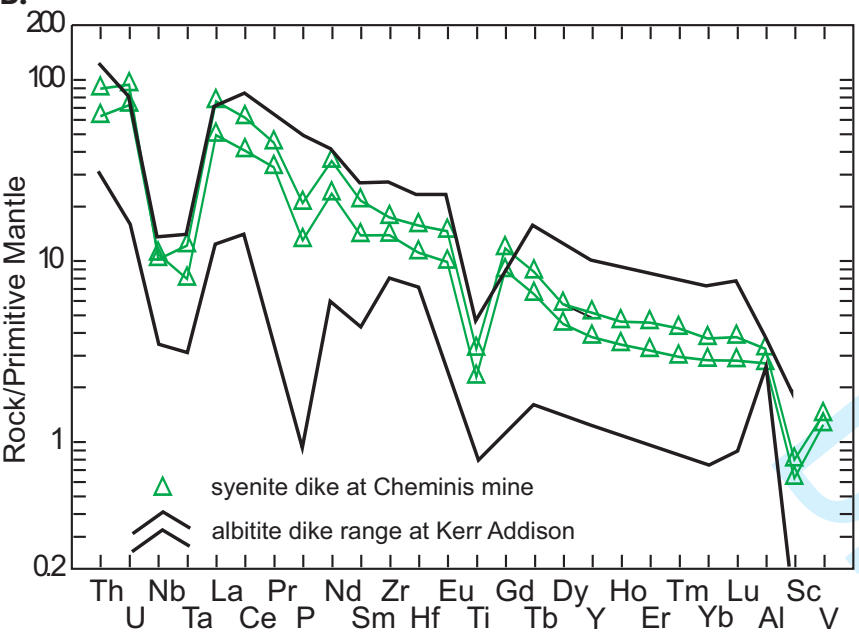

Figure 12: Lafrance 

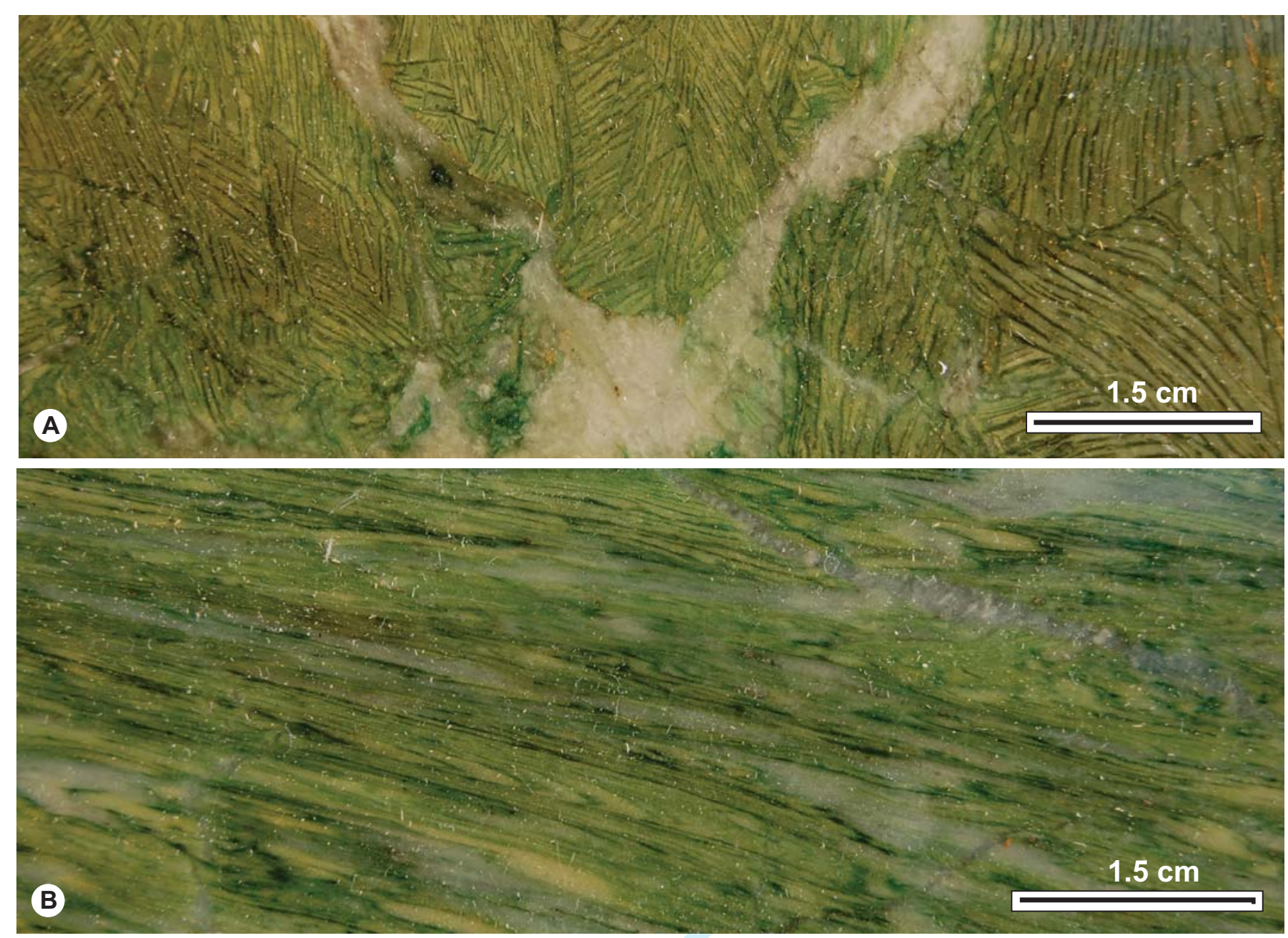

Figure 13: Lafrance 
Table 1: Concentration data for major elements (wt.\%) and trace elements (ppm) for representative samples

\begin{tabular}{|c|c|c|c|c|c|c|c|c|c|c|c|c|}
\hline \multirow{2}{*}{$\begin{array}{l}\text { Sample No. } \\
\text { Rock Type }\end{array}$} & & \multicolumn{2}{|c|}{ U-Unmin U-310 } & \multirow{2}{*}{$\begin{array}{c}\text { U-321 } \\
\text { S-M }\end{array}$} & \multirow{2}{*}{$\begin{array}{c}\text { 2004-3 } \\
\text { SYE }\end{array}$} & \multirow{2}{*}{$\begin{array}{c}\mathbf{N}-\mathbf{3 5}-63 \\
\text { GreenU }\end{array}$} & \multirow{2}{*}{$\begin{array}{l}\mathbf{N - 8 - 3 3} \\
\text { GrayU }\end{array}$} & \multirow{2}{*}{$\begin{array}{c}\text { N-8-6 } \\
\text { BlackU }\end{array}$} & \multirow{2}{*}{$\begin{array}{c}\text { N-11-17 } \\
\text { B-LA }\end{array}$} & \multirow{2}{*}{$\begin{array}{c}\text { 05-KL-9B } \\
\text { B-M }\end{array}$} & \multirow{2}{*}{$\begin{array}{c}\text { N-8-17.5 } \\
\text { B-M }\end{array}$} & \multirow{2}{*}{$\begin{array}{c}\text { N-12-25 } \\
\text { B-M }\end{array}$} \\
\hline & & S-LA & S-M & & & & & & & & & \\
\hline \multicolumn{13}{|c|}{ Major oxides Method } \\
\hline $\mathrm{SiO}_{2}$ & FUS-ICP & 57.59 & 49.39 & 53.05 & 52.26 & 31.98 & 32.67 & 41.27 & 53.08 & 52.92 & 22.92 & 23.09 \\
\hline $\mathrm{Al}_{2} \mathrm{O}_{3}$ & FUS-ICP & 16.18 & 16.43 & 11.10 & 12.44 & 5.14 & 5.36 & 6.09 & 13.72 & 10.99 & 13.1 & 14.53 \\
\hline $\mathrm{Fe}_{2} \mathrm{O}_{3}$ & FUS-ICP & 9.31 & 10.43 & 8.21 & 7.16 & 8.32 & 8.74 & 9.66 & 16.69 & 8.37 & 16.44 & 13.7 \\
\hline $\mathrm{MnO}$ & FUS-ICP & 0.05 & 0.04 & 0.09 & 0.13 & 0.18 & 0.22 & 0.091 & 0.15 & 0.29 & 0.248 & 0.291 \\
\hline $\mathrm{MgO}$ & FUS-ICP & 4.18 & 2.01 & 3.20 & 4.24 & 15.77 & 15.37 & 24.79 & 4.06 & 3.23 & 5.42 & 5.69 \\
\hline $\mathrm{CaO}$ & FUS-ICP & 1.15 & 2.13 & 4.49 & 5.63 & 10.58 & 13.69 & 4.47 & 1.64 & 5.41 & 10.59 & 12.74 \\
\hline $\mathrm{Na}_{2} \mathrm{O}$ & FUS-ICP & 2.66 & 2.32 & 2.97 & 6.27 & 0.25 & 0.02 & 0.05 & 2.94 & 5.11 & 0.85 & 1.26 \\
\hline $\mathrm{K}_{2} \mathrm{O}$ & FUS-ICP & 2.77 & 3.59 & 1.19 & 2.67 & 1.27 & 0.03 & 0.03 & 0.70 & 2.08 & 3.65 & 3.99 \\
\hline $\mathrm{TiO}_{2}$ & FUS-ICP & 0.88 & 1.00 & 0.65 & 0.49 & 0.30 & 0.31 & 0.333 & 2.13 & 1.51 & 1.771 & 2.145 \\
\hline $\mathrm{P}_{2} \mathrm{O}_{5}$ & FUS-ICP & 0.17 & 0.15 & 0.02 & 0.28 & $<0.01$ & 0.02 & 0.03 & 0.20 & 0.03 & $<0.01$ & $<0.01$ \\
\hline LOI & FUS-ICP & 3.78 & 7.90 & 11.13 & 9.10 & 25.95 & 21.51 & 9.45 & 4.21 & 10.52 & 15.13 & 17.06 \\
\hline Total & & 98.72 & 95.39 & 96.09 & 100.70 & 99.76 & 97.94 & 96.25 & 99.51 & 100.50 & 90.08 & 94.48 \\
\hline $\mathrm{CO}_{2}$ & COUL & 1.20 & 3.09 & 7.41 & 7.94 & 27.2 & 21.70 & 7.03 & 7.44 & 11.9 & 17.5 & 20.4 \\
\hline $\mathrm{S}$ & TD-ICP & 0.10 & 6.45 & 3.38 & 2.58 & 0.94 & 0.15 & 0.134 & 0.84 & 1.04 & 8.42 & 5.29 \\
\hline \multicolumn{13}{|c|}{ Trace elements Method } \\
\hline V & FUS-ICP & 200 & 204 & 139 & 101 & 111 & 108 & 117 & 483 & 373 & 435 & 497 \\
\hline $\mathrm{Sr}$ & FUS-ICP & 100 & 164 & 217 & 207 & 306 & 91 & 86 & 81 & 63 & 144 & 130 \\
\hline $\mathrm{Ba}$ & FUS-ICP & 355 & 512 & 175 & 115 & 330 & 8 & 10 & 158 & 109 & 648 & 553 \\
\hline Co & FUS-MS & 36 & 43 & 31 & 14 & 64 & 107 & 98 & 79 & 23 & 47 & 54 \\
\hline $\mathrm{Ga}$ & FUS-MS & 22 & 21 & 13 & 14 & 7 & 7 & 6 & 21 & 15 & 23 & 24 \\
\hline $\mathrm{Ge}$ & FUS-MS & 1.9 & 1.7 & 1.5 & 0.8 & 0.8 & 0.6 & 1.5 & 1.1 & 0.9 & 0.9 & 0.9 \\
\hline $\mathrm{Rb}$ & FUS-MS & 54 & 110 & 37 & 2 & 35 & $<1$ & $<1$ & 23 & 17 & 65 & 61 \\
\hline $\mathrm{Y}$ & FUS-MS & 24.4 & 22.1 & 14.1 & 17.1 & 6.6 & 7.4 & 7.0 & 39.5 & 38.2 & 36.1 & 37.8 \\
\hline $\mathrm{Zr}$ & FUS-MS & 139 & 130 & 95 & 154 & 18 & 18 & 17 & 111 & 111 & 101 & 127 \\
\hline $\mathrm{Nb}$ & FUS-MS & 6.1 & 6.0 & 4.1 & 7.7 & 0.8 & 0.8 & 0.7 & 5.6 & 5.6 & 4.6 & 5.8 \\
\hline $\mathrm{Sb}$ & FUS-MS & 12.1 & 42.7 & 55.4 & 2.4 & 60.7 & 23.8 & 2.7 & 41.6 & 2.9 & 21.7 & 12.8 \\
\hline Cs & FUS-MS & 2.3 & 3.3 & 1.1 & 0.2 & 1.2 & 0.2 & 0.5 & 0.4 & 0.3 & 1.4 & 1.0 \\
\hline $\mathrm{Bi}$ & FUS-MS & 0.3 & 1.2 & 0.9 & $<0.1$ & $<0.1$ & $<0.1$ & 0.1 & 0.1 & $<0.1$ & 0.4 & 0.2 \\
\hline La & FUS-MS & 16.50 & 15.60 & 12.80 & 33.70 & 0.89 & 0.51 & 1.12 & 6.72 & 5.81 & 5.18 & 6.35 \\
\hline $\mathrm{Ce}$ & FUS-MS & 36.50 & 35.50 & 27.80 & 71.50 & 2.51 & 1.59 & 2.91 & 18.50 & 16.10 & 14.50 & 17.1 \\
\hline $\operatorname{Pr}$ & FUS-MS & 4.71 & 4.65 & 3.56 & 8.99 & 0.41 & 0.29 & 0.46 & 2.96 & 2.59 & 2.38 & 2.8 \\
\hline $\mathrm{Nd}$ & FUS-MS & 17.30 & 17.30 & 12.90 & 31.50 & 2.12 & 1.70 & 2.27 & 14.10 & 12.40 & 12.30 & 13 \\
\hline Sm & FUS-MS & 3.95 & 3.82 & 2.80 & 6.08 & 0.68 & 0.59 & 0.69 & 4.33 & 3.83 & 3.68 & 3.87 \\
\hline $\mathrm{Eu}$ & FUS-MS & 1.12 & 1.12 & 0.86 & 1.64 & 0.29 & 0.30 & 0.19 & 1.26 & 0.89 & 1.08 & 1.25 \\
\hline $\mathrm{Gd}$ & FUS-MS & 4.16 & 4.01 & 2.87 & 5.23 & 0.95 & 0.94 & 1.03 & 6.10 & 5.06 & 5.10 & 5.37 \\
\hline $\mathrm{Tb}$ & FUS-MS & 0.73 & 0.70 & 0.49 & 0.70 & 0.19 & 0.19 & 0.20 & 1.18 & 0.99 & 1.01 & 1.05 \\
\hline Dy & FUS-MS & 4.32 & 4.06 & 2.84 & 3.27 & 1.20 & 1.22 & 1.32 & 7.45 & 6.34 & 6.61 & 6.87 \\
\hline Ho & FUS-MS & 0.83 & 0.80 & 0.52 & 0.56 & 0.24 & 0.25 & 0.26 & 1.49 & 1.28 & 1.36 & 1.39 \\
\hline $\mathrm{Er}$ & FUS-MS & 2.38 & 2.34 & 1.51 & 1.52 & 0.69 & 0.71 & 0.75 & 4.45 & 3.76 & 4.01 & 4.12 \\
\hline $\mathrm{Tm}$ & FUS-MS & 0.35 & 0.35 & 0.24 & 0.22 & 0.10 & 0.10 & 0.12 & 0.67 & 0.57 & 0.60 & 0.63 \\
\hline $\mathrm{Yb}$ & FUS-MS & 2.21 & 2.28 & 1.51 & 1.38 & 0.67 & 0.64 & 0.74 & 4.32 & 3.56 & 4.01 & 4.06 \\
\hline Lu & FUS-MS & 0.34 & 0.35 & 0.22 & 0.21 & 0.10 & 0.10 & 0.11 & 0.68 & 0.54 & 0.64 & 0.647 \\
\hline
\end{tabular}

Notes: Total $\mathrm{Fe}$ as $\mathrm{Fe}_{2} \mathrm{O}_{3}$; LOI, loss on ignition; S-LA, least altered sandstone; S-M, mineralized sandstone; SYE, syenite dike; GreenU, fuchsite-carbonate ultramafic rock; GrayU, chlorite-carbonate ultramafic rock; BlackU, talc-chlorite ultramafic rock; B-LA, least altered tholeiitic basalt; B-M, mineralized tholeiitic basalt; FUS-ICP, lithium metaborate \& tetraborate fusion ICP; FUS-MS, lithium metaborate \& tetraborate fusion ICP-MS; TD-ICP, total four acid digestion ICP; INAA, instrumental neutron activation analysis; AR-MS, aqua regia digestion ICP-MS 
Table 1 (continued)

\begin{tabular}{|c|c|c|c|c|c|c|c|c|c|c|c|c|}
\hline \multirow{2}{*}{$\begin{array}{l}\text { Sample No. } \\
\text { Rock Type }\end{array}$} & & \multicolumn{2}{|c|}{ U-Unmin U-310 } & \multirow{2}{*}{$\begin{array}{c}\text { U-321 } \\
\text { S-M }\end{array}$} & \multirow{2}{*}{$\begin{array}{c}\text { 2004-3 } \\
\text { SYE }\end{array}$} & \multirow{2}{*}{$\begin{array}{c}\mathbf{N - 3 5 - 6 3} \\
\text { GreenU }\end{array}$} & \multirow{2}{*}{$\begin{array}{l}\mathbf{N - 8 - 3 3} \\
\text { GrayU }\end{array}$} & \multirow{2}{*}{$\begin{array}{c}\text { N-8-6 } \\
\text { BlackU }\end{array}$} & \multirow{2}{*}{$\begin{array}{c}\text { N-11-17 } \\
\text { B-LA }\end{array}$} & \multirow{2}{*}{$\begin{array}{c}\text { 05-KL-9B } \\
\text { B-M }\end{array}$} & \multirow{2}{*}{$\begin{array}{c}\mathbf{N - 8 - 1 7 . 5} \\
\text { B-M }\end{array}$} & \multirow{2}{*}{$\begin{array}{c}\text { N-12-25 } \\
\text { B-M }\end{array}$} \\
\hline & & S-LA & $\mathrm{S}-\mathrm{IVI}$ & & & & & & & & & \\
\hline \multicolumn{13}{|c|}{ Trace elements Method } \\
\hline $\mathrm{Hf}$ & FUS-MS & 3.6 & 3.6 & 2.5 & 3.4 & 0.6 & 0.5 & 0.5 & 3.3 & 2.8 & 3.0 & 3.7 \\
\hline $\mathrm{Ta}$ & FUS-MS & 0.42 & 0.40 & 0.24 & 0.32 & 0.02 & 0.04 & 0.03 & 0.29 & 0.22 & 0.25 & 0.30 \\
\hline Th & FUS-MS & 3.00 & 2.57 & 1.98 & 5.30 & 0.08 & $<0.05$ & 0.11 & 0.59 & 0.57 & 0.51 & 0.60 \\
\hline W & FUS-MS & 2.6 & 10.0 & 7.8 & 6.6 & 6.9 & 5.7 & 1.7 & 3.8 & 92.3 & 98.2 & 189.0 \\
\hline $\mathrm{TI}$ & FUS-MS & 0.26 & 0.22 & 0.08 & $<0.05$ & 0.23 & $<0.05$ & $<0.05$ & 0.14 & 0.07 & 0.14 & 0.09 \\
\hline$U$ & FUS-MS & 0.84 & 0.69 & 0.54 & 1.51 & 0.04 & 0.06 & 0.06 & 0.17 & 0.18 & 0.16 & 0.16 \\
\hline $\mathrm{Cd}$ & TD-ICP & 1.4 & 2.7 & 2.2 & 2.0 & 2.1 & 2.2 & 0.8 & 1.0 & 0.8 & 3.0 & 2.2 \\
\hline $\mathrm{Ni}$ & TD-ICP & 101 & 167 & 163 & 39 & 728 & 1140 & 1200 & 294 & 45 & 47 & 173 \\
\hline $\mathrm{Cu}$ & TD-ICP & 55 & 43 & 111 & 44 & 68 & 58 & 93 & 112 & 101 & 276 & 165 \\
\hline $\mathrm{Zn}$ & TD-ICP & 79 & 32 & 31 & 28 & 47 & 54 & 49 & 106 & 36 & 52 & 45 \\
\hline $\mathrm{Ag}$ & TD-ICP & $<0.5$ & 0.5 & 0.9 & 1.1 & $<0.5$ & $<0.5$ & $<0.5$ & $<0.5$ & $<0.5$ & 1.9 & 0.7 \\
\hline $\mathrm{Au}$ & INAA & 0.06 & 1.53 & 11.00 & 0.53 & 1.81 & 0.05 & 0.08 & 0.03 & 0.23 & 10.20 & 1.69 \\
\hline As & INAA & 332 & 16,900 & 26,500 & 1,600 & 1,280 & 509 & 20 & 160 & 132 & 643 & 483 \\
\hline $\mathrm{Cr}$ & INAA & 256 & 276 & 189 & 64 & 1,490 & 1,920 & 2,220 & 18 & 13 & 24 & 55 \\
\hline Sc & INAA & 27.6 & 28.8 & 16.1 & 10.6 & 17.6 & 18.3 & 20.2 & 45.6 & 31.6 & 43.2 & 46.9 \\
\hline $\mathrm{Sb}$ & INAA & 3.3 & 8.1 & 9.2 & $<0.2$ & 57.5 & 20.3 & 1.6 & 48.0 & 1.4 & 9.7 & 6.9 \\
\hline $\mathrm{Au}$ & AR-MS & & & $>10$ & 0.56 & 1.66 & & & & 0.33 & $>10$ & 1.60 \\
\hline $\mathrm{Ag}$ & AR-MS & & & 0.85 & 0.54 & 0.10 & & & & 0.14 & 1.57 & 0.34 \\
\hline As & AR-MS & & & $>10000$ & 1,660 & 1,180 & & & & 134 & 617 & 438 \\
\hline W & AR-MS & & & 0.2 & 0.1 & 0.1 & & & & 0.5 & 2.5 & 1.0 \\
\hline $\mathrm{Zn}$ & AR-MS & & & 26.7 & 33.1 & 40.2 & & & & 41.2 & 61.0 & 50.7 \\
\hline $\mathrm{Cu}$ & AR-MS & & & 120.0 & 43.6 & 62.1 & & & & 101.0 & 266.0 & 158.0 \\
\hline $\mathrm{Pb}$ & AR-MS & & & 5.28 & 5.41 & 2.70 & & & & 1.72 & 7.74 & 2.9 \\
\hline $\mathrm{Bi}$ & AR-MS & & & 0.16 & 0.09 & $<0.02$ & & & & $<0.02$ & 0.17 & 0.03 \\
\hline Te & AR-MS & & & 0.07 & 3.20 & $<0.02$ & & & & 0.24 & 0.52 & 0.16 \\
\hline Mo & AR-MS & & & 1.88 & 0.08 & $<0.01$ & & & & 0.07 & 0.14 & 0.14 \\
\hline $\mathrm{Sb}$ & AR-MS & & & 40.80 & 1.51 & 45.50 & & & & 0.59 & 6.04 & 3.82 \\
\hline Sn & AR-MS & & & $<0.05$ & 0.32 & $<0.05$ & & & & 0.09 & 0.08 & 0.1 \\
\hline $\mathrm{Se}$ & AR-MS & & & 1.1 & 0.9 & 0.3 & & & & 0.3 & 3.0 & 1.6 \\
\hline
\end{tabular}


Table 2: Average mineral compositions

\begin{tabular}{|c|c|c|c|c|c|c|}
\hline Rock Type & S-M & GreenU & GrayU & BlackU & B-LA & B-M \\
\hline Carbonate & Ankerite (2) & Ferroan dolomite (9 & ) Ferroan dolomite (9) & Ferroan dolomite (7) & Ankerite (7) & Ankerite (14) \\
\hline $\mathrm{Fe} / \mathrm{Fe}+\mathrm{Mg}$ & 0.3 & 0.11 & 0.13 & 0.20 & 0.55 & 0.31 \\
\hline $\mathrm{Mg \#}$ & 0.67 & 0.88 & 0.86 & 0.78 & 0.41 & 0.68 \\
\hline Chlorite & (2) & & (4) & (3) & (5) & (4) \\
\hline $\mathrm{Fe} / \mathrm{Fe}+\mathrm{Mg}$ & 0.50 & & 0.17 & 0.30 & 0.74 & 0.49 \\
\hline $\mathrm{Mg \#}$ & 0.50 & & 0.83 & 0.70 & 0.26 & 0.51 \\
\hline Atomic $\% \mathrm{Al}$ & 10.27 & & 7.41 & 7.59 & 10.01 & 9.00 \\
\hline White mica & Sericite (5) & Fuchsite (8) & & & Sericite (3) & Sericite (11) \\
\hline $\mathrm{Fe} / \mathrm{Fe}+\mathrm{Mg}$ & 0.39 & 0.15 & & & 0.55 & 0.34 \\
\hline $\mathrm{Mg \#}$ & 0.61 & 0.85 & & & 0.45 & 0.66 \\
\hline $\mathrm{Al} \mathrm{IV}$ & 0.88 & 0.90 & & & 0.96 & 0.97 \\
\hline $\mathrm{Al} \mathrm{VI}$ & 1.84 & 1.80 & & & 1.82 & 1.80 \\
\hline Magnesite-Siderite & & (16) & (10) & & & \\
\hline $\mathrm{Fe} / \mathrm{Fe}+\mathrm{Mg}$ & & 0.19 & 0.19 & & & \\
\hline Mg\# & & 0.81 & 0.80 & & & \\
\hline
\end{tabular}

Notes: Number of analyses in parenthesis; S-M, mineralized sandstone; GreenU, fuchsite-carbonate ultramafic rock; GrayU, chloritecarbonate ultramafic rock; BlackU, talc-chlorite ultramafic rock; B-LA, least altered tholeiitic basalt; B-M, mineralized tholeiitic basalt 